\title{
Sex-Specific Vasopressin Signaling Buffers Stress-Dependent Synaptic Changes in Female Mice
}

\author{
Spencer P. Loewen, Dinara V. Baimoukhametova, and ${ }^{\circ}$ Jaideep S. Bains \\ Hotchkiss Brain Institute and Department of Physiology and Pharmacology, Cumming School of Medicine, University of Calgary, Calgary, Alberta, \\ Canada T2N 4N1
}

In many species, social networks provide benefit for both the individual and the collective. In addition to transmitting information to others, social networks provide an emotional buffer for distressed individuals. Our understanding about the cellular mechanisms that contribute to buffering is poor. Stress has consequences for the entire organism, including a robust change in synaptic plasticity at glutamate synapses onto corticotropin-releasing hormone (CRH) neurons in the paraventricular nucleus of the hypothalamus (PVN). In females, however, this stress-induced metaplasticity is buffered by the presence of a naive partner. This buffering may be because of discrete behavioral interactions, signals in the context in which the interaction occurs (i.e., olfactory cues), or it may be influenced by local signaling events in the PVN. Here, we show that local vasopressin (VP) signaling in PVN buffers the short-term potentiation (STP) at glutamate synapses after stress. This social buffering of metaplasticity, which requires the presence of another individual, was prevented by pharmacological inhibition of the VP 1a receptor (V1aR) in female mice. Exogenous VP mimicked the effects of social buffering and reduced STP in $\mathrm{CRH}^{\mathrm{PVN}}$ neurons from females but not males. These findings implicate VP as a potential mediator of social buffering in female mice.

Key words: CRH; hypothalamus; social; stress; synapse; vasopressin

\section{Significance Statement}

In many organisms, including rodents and humans, social groups are beneficial to overall health and well-being. Moreover, it is through these social interactions that the harmful effects of stress can be mitigated, a phenomenon known as social buffering. In the present study, we describe a critical role for the neuropeptide vasopressin (VP) in social buffering of synaptic metaplasticity in stress-responsive corticotropin-releasing hormone (CRH) neurons in female mice. These effects of VP do not extend to social buffering of stress behaviors, suggesting this is a very precise and local form of sex-specific neuropeptide signaling.

\section{Introduction}

Many species, including rodents and humans, transmit and receive information through social interactions. These interactions are vital for many functions, including survival, reproduction, resource allocation, and affiliation (Krause and Ruxton, 2002; Silk, 2007). This complexity is one reason our understanding of this critical biological processes is limited. Understanding social behavior, and, specifically, social behavior in specific circumstances, requires a detailed understanding of the brain at

\footnotetext{
Received Apr. 30, 2020; revised Sep. 21, 2020; accepted Sep. 27, 2020.

Author contributions: S.P.L. and J.S.B. designed research; S.P.L. and D.V.B. performed research; S.P.L., D.V.B., and J.S.B. analyzed data; S.P.L. and J.S.B. wrote the paper.

This work was supported by the Canadian Institutes of Health Research (CIHR) Grant FDN-148440 (to J.S.B.). S.P.L. is the recipient of a CIHR Doctoral Research Award. We thank Cheryl Breiteneder for technical assistance.

The authors declare no competing financial interests.

Correspondence should be addressed to Jaideep S. Bains at jsbains@ucalgary.ca.

https://doi.org/10.1523/JNEUROSCI.1026-20.2020

Copyright $\odot 2020$ the authors
}

multiple levels from circuits to synapses to cells. In many species, social behaviors show sexual divergence; males and females show distinct features of social behavior related to parenting (Lonstein and De Vries, 2000), aggression (Archer, 2009), affiliative behavior (Taylor et al., 2000), and empathy (Christov-Moore et al., 2014). The neuropeptides oxytocin (OT) and vasopressin (VP) play critical roles in many social behaviors (Johnson and Young, 2017), and there has been increasing attention given to the role of OT and VP as sexually dimorphic social signals (de Vries, 2008; Dumais and Veenema, 2016). How they specifically modulate neuronal or synaptic function in a sex-specific fashion within the context of the social brain, however, is not clear.

Social interactions also leave enduring marks on the brain. We have recently shown that social interactions can transmit negative affective states and cause changes at the level of glutamate synapses in first and second order recipients of stress (Sterley et al., 2018). These changes result in a stress-induced metaplasticity at glutamate synapses onto corticotropin-releasing hormone $(\mathrm{CRH})$ neurons in the hypothalamic paraventricular 
nucleus (PVN; Sterley et al., 2018), which are adjacent to both OT and VP neurons within this structure (Biag et al., 2012). Intriguingly, social interactions also result in a decrease in the synaptic changes in female individuals subjected directly to stress (Sterley et al., 2018). Conversely, both social isolation and acute stress have similar effects on the biophysical properties of $\mathrm{CRH}^{\mathrm{PVN}}$ neurons in females (Senst et al., 2016). These findings suggest that the long-term consequences of stress are impacted by social interactions in a sexually dimorphic fashion. However, the mechanisms responsible for the sex-specific curtailment of synaptic changes following social interaction are not known.

Multiple lines of evidence suggest that neurons in the PVN are sensitive to neuromodulation by locally released substances (Landgraf and Neumann, 2004; Ludwig and Leng, 2006). These substances, which include CRH (Kuzmiski et al., 2010; Ramot et al., 2017; Jiang et al., 2018), dynorphin (Iremonger and Bains, 2009), enkephalin (Wamsteeker Cusulin et al., 2013a), OT (Kombian et al., 1997; Oliet et al., 2007), and VP (Ludwig, 1998), are released from the somatodendritic compartments of PVN neurons. Intranuclear release of VP in the PVN following social defeat or forced swimming exerts an inhibitory effect on hypothalamic-pituitary-adrenal (HPA) axis activation and subsequent ACTH secretion (Wotjak et al., 1996, 1998). Dendritically released VP from magnocellular neurosecretory cells can affect the excitability of preautonomic neurons up to $100 \mu \mathrm{m}$ away (Son et al., 2013). These cellular effects, combined with the involvement of VP in pair-bonding and affiliative behaviors (Young and Wang, 2004; Insel, 2010), the demonstration that VP neurons in the PVN are selectively targeted by a synaptic relay from olfactory bulb neurons that express a family of olfactory receptors [odorant receptor 37 (OR37)] that buffer the effects of stress (Bader et al., 2012; Klein et al., 2015), and the adjacent cytoarchitectural arrangement of CRH and VP neurons in the PVN (Biag et al., 2012), led us to hypothesize that local release of VP in the PVN may contribute to social buffering of synaptic metaplasticity in females.

Here, we demonstrate that the presence of others reduces stress-induced grooming behavior and metaplasticity at glutamate synapses onto CRH ${ }^{\mathrm{PVN}}$ neurons in female mice. The effects on synapses, but not behavior, require local actions of VP at VP la receptors (V1aRs) on $\mathrm{CRH}^{\mathrm{PVN}}$ neurons, suggesting that VP has sex-specific neuromodulatory effects that "erase" the synaptic effects of a stressful experience in females.

\section{Materials and Methods \\ Animals}

All animal protocols conformed to the standards of the Canadian Council on Animal Care and were approved by the University of Calgary Animal Care and Use Committee. Experiments were performed on three- to five-week-old male and female Crh-IRES-Cre; Ai14 mice in which CRH neurons express a tdTomato fluorophore (Wamsteeker Cusulin et al., 2013b). Mice were housed in whole litters on a 12/12 h light/dark cycle (lights on at 6 A.M.) and were provided with food and water ad libitum. At least $16 \mathrm{~h}$ before acute stress or slice preparation, mice were housed either alone or in same-sex littermate pairs, depending on the experiment. Mice were randomly assigned to the experimental groups. Stress was induced between 9:30 and 10:30 A.M. during the light phase by subjecting mice to a footshock (FS) protocol consisting of a $0.5 \mathrm{~mA}$ FS for $2 \mathrm{~s}$ delivered every $30 \mathrm{~s}$ over a 5 -min period. In experiments involving injection of the selective V1aR antagonist, SR 49059 (SR; Sigma-Aldrich), SR was initially dissolved in dimethylsulfoxide (DMSO) and then in polyethylene glycol (PEG) and injected intraperitoneally $5 \mathrm{~min}$ before FS at a dose of $2 \mathrm{mg} / \mathrm{kg}$ in a final volume of $50 \mu \mathrm{l}(5 \%$ DMSO, 95\% PEG). Control mice received a $50-\mu \mathrm{l}$ vehicle injection of
PEG and DMSO. Mice were video recorded for $30 \mathrm{~min}$ following return of the FS mouse to the homecage. Videos were analyzed and scored for grooming (grooming with forepaws, scratching, fur licking; Füzesi et al., 2016), anogenital sniffing (directing the snout toward the anogenital region of the conspecific), and head/torso sniffing (directing the snout toward the head or torso of the conspecific). Social discrimination indices were generated by dividing the amount of time spent sniffing the anogenital region of the conspecific by the total amount of time spent sniffing both the anogenital and head/torso regions of the conspecific.

\section{Slice preparation}

Immediately following FS or the 30-min social interaction, mice were anesthetized with isofluorane and decapitated. Brains were rapidly removed and immersed in ice-cold $\left(0-4^{\circ} \mathrm{C}\right)$ slicing solution consisting of the following: $87 \mathrm{~mm} \mathrm{NaCl}, 2.5 \mathrm{~mm} \mathrm{KCl}, 0.5 \mathrm{~mm} \mathrm{CaCl}_{2}, 7 \mathrm{~mm} \mathrm{MgCl}, 25$ mм NaHCO $325 \mathrm{~mm}$ D-glucose, $1.25 \mathrm{~mm} \mathrm{NaH}_{2} \mathrm{PO}_{4}$, and $75 \mathrm{~mm}$ sucrose and saturated with $95 \% \mathrm{O}_{2} / 5 \% \mathrm{CO}_{2}$. Brains were blocked and $250-\mu \mathrm{m}$ coronal sections containing the PVN were obtained using a vibratome (VT1200S, Leica). Slices recovered for $1 \mathrm{~h}$ in $30^{\circ} \mathrm{C}$ artificial CSF (aCSF) consisting of the following: $126 \mathrm{~mm} \mathrm{NaCl}, 2.5 \mathrm{~mm} \mathrm{KCl}, 26 \mathrm{~mm} \mathrm{NaHCO}_{3}$, $2.5 \mathrm{~mm} \mathrm{CaCl}_{2}, 1.5 \mathrm{~mm} \mathrm{MgCl}_{2}, 1.25 \mathrm{~mm} \mathrm{NaH}_{2} \mathrm{PO}_{4}$, and $10 \mathrm{~mm}$ glucose and saturated with $95 \% \mathrm{O}_{2} / 5 \% \mathrm{CO}_{2}$. Following the 1-h recovery period, slices treated with VP were transferred to a separate chamber containing $100 \mathrm{~nm}$ VP dissolved in aCSF for $30 \mathrm{~min}$ before recording. In a subset of experiments, slices were preincubated in $10 \mu \mathrm{M}$ SR dissolved in aCSF for $10 \mathrm{~min}$ before incubation in both VP and SR for an additional $30 \mathrm{~min}$.

\section{Electrophysiology}

Slices were transferred to a recording chamber superfused with $30-32^{\circ} \mathrm{C}$ aCSF at a flow rate of $1-2 \mathrm{ml} / \mathrm{min}$. All recordings took place in aCSF containing $100 \mu \mathrm{m}$ picrotoxin unless otherwise stated. Neurons were visualized using a $40 \times$ water-immersion objective mounted on an upright microscope (BX51WI, Olympus) fitted with differential interference contrast optics, a metal halide fluorescence lamp (X-Cite Series 120, EXFO), and a digital camera (OLY-150, Olympus). $\mathrm{CRH}^{\mathrm{PVN}}$ neurons were identified based on their location and tdTomato fluorescence. Borosilicate glass micropipettes were pulled on a horizontal micropipette puller (P-97, Sutter Instruments) to tip resistances between 2.5 and 5 $\mathrm{M} \Omega$ when filled with the intracellular solution consisting of the following: $108 \mathrm{~mm}$ K-gluconate, $2 \mathrm{~mm} \mathrm{MgCl}_{2}, 8 \mathrm{~mm} \mathrm{Na}$-gluconate, $8 \mathrm{~mm} \mathrm{KCl}$, $1 \mathrm{~mm} \mathrm{~K}_{2}$-EGTA, 4 mм K $\mathrm{K}_{2}$-ATP, and $0.3 \mathrm{~mm} \mathrm{Na}_{3}$-GTP buffered with 10 mM HEPES. EPSCs were evoked $50 \mathrm{~ms}$ apart at $0.2-\mathrm{Hz}$ intervals using a monopolar aCSF-filled electrode placed in the neuropil surrounding the cell $(\sim 20 \mu \mathrm{M})$. High-frequency stimulation (HFS) consisted of four 100$\mathrm{Hz}$ stimulations for $1 \mathrm{~s}$ every $10 \mathrm{~s}$. AMPAR-mediated EPSCs were isolated by holding the postsynaptic neuron at $-70 \mathrm{mV}$ to block voltagedependent postsynaptic NMDARs. NMDAR-mediated currents were recorded at a holding potential of $+40 \mathrm{mV}$ using an intracellular solution consisting of the following: $130 \mathrm{~mm} \mathrm{CsCl}, 10 \mathrm{~mm} \mathrm{NaCl}, 10 \mathrm{~mm}$ EGTA, $0.1 \mathrm{~mm} \mathrm{CaCl}_{2}, 4 \mathrm{~mm} \mathrm{~K}_{2}$-ATP, and $0.3 \mathrm{~mm} \mathrm{Na}_{3}$-GTP buffered with 10 mM HEPES. To assess the effects of acute VP application on isolated NMDAR-mediated currents, the AMPA antagonist DNQX was included in the aCSF and EPSCs were evoked at a rate of $1 \mathrm{~Hz}$. In some experiments, GTP was replaced with $1 \mathrm{~mm}$ guanosine $5^{\prime}$-[ $\beta$-thio] diphosphate trilithium salt (GDP $\beta$ S; Sigma-Aldrich). In the indicated experiments, VP was applied to slices via syringe pump (R-99, Razel Scientific Instruments) or focally to cells via a puff pipette (20 psi, $1 \mathrm{~s})$ connected to a Picospritzer II microcellular injection unit (General Valve). Access resistance $(<20 \mathrm{M} \Omega)$ was continuously monitored throughout the experiments; recordings were excluded from analysis if it exceeded a $15 \%$ change.

\section{Data analysis and statistics}

Signals were amplified using a MultiClamp 700B amplifier (Molecular Devices), low-pass filtered at $1 \mathrm{kHz}$, and digitized at $10 \mathrm{kHz}$ using the Digidata 1440A (Molecular Devices). Data were recorded (pClamp 10.4, Molecular Devices) and stored on a computer for offline analysis. Evoked EPSC amplitude was calculated from the baseline current before stimulation to the peak synaptic current. The magnitude was calculated 
as the average amplitude of 12 evoked EPSCs immediately following HFS (0-1 min post-HFS). The mean firing frequency and membrane potential values were calculated from the 1-min baseline period immediately before VP application and a 20-s period around the peak effect. The AMPA/NMDA ratio was determined by averaging 15 AMPARmediated EPSC traces and 15 NMDAR-mediated EPSC traces per cell. The peak amplitude of the AMPAR-mediated current was measured as the peak of the EPSC. The peak amplitude of the NMDAR-mediated current was measured $15 \mathrm{~ms}$ after the AMPAR-mediated EPSC peak. The magnitude of the effect of VP on isolated NMDAR-mediated currents was determined as the mean amplitude during each minute over the 15- to 20-min period following VP application and was measured at the peak of the EPSC. Histograms for grooming, locomotion, and sniffing were created based on the percentage of animals exhibiting each behavior during each second over the 30-min observation period and then binned into 30 -s intervals. Statistical analyses were performed using GraphPad Prism 6.04. Two-tailed $t$ tests were used to compare post-HFS to $100 \%$ baseline. Unpaired $t$ tests were used to compare the means of two independent groups. Paired $t$ tests were used to compare the means of two dependent groups. A one-way ANOVA was used to compare the means of multiple groups, followed by Sidak's post hoc, multiple comparisons tests. Data are presented as mean \pm SEM.

\section{Results}

\section{Social buffering of stress-induced grooming behavior and} short-term potentiation (STP)

$\mathrm{CRH}^{\mathrm{PVN}}$ neurons play a crucial role in multiple stress-related behaviors (Füzesi et al., 2016; Zhang et al., 2017; Sterley et al., 2018; Daviu et al., 2020). Immediately after an acute stress, $\mathrm{CRH}^{\mathrm{PVN}}$ neurons, through collateral projections to the lateral hypothalamus, drive self-grooming (Füzesi et al., 2016). We assessed whether the presence of a partner attenuates grooming. A single-housed female mouse (Fig. $1 A$ ) or one mouse from a female dyad of littermates (Fig. $1 B$ ) was subjected to FS stress and then returned to its homecage for $30 \mathrm{~min}$; spontaneous behavior of both mice was recorded during this time. Singlehoused female mice spent more time grooming than pair-housed female mice (single-housed, 467.2 $\pm 41.6 \mathrm{~s}, N=10$; pair-housed, $308.6 \pm 25.6 \mathrm{~s}, N=8 ; p=0.008$, unpaired $t$ test, two-tailed, $t_{(16)}=3.1$; Fig. $\left.1 C i-E\right)$. The duration of locomotor activity was not different between single-housed and pair-housed female FS mice (single-housed, $277.9 \pm 11.8 \mathrm{~s}, N=10$; pair-housed, $287.9 \pm$ $33.8 \mathrm{~s}, N=8$; $p=0.77$, unpaired $t$ test, two-tailed, $t_{(16)}=0.30$; Fig. $1 F i-G)$. One possibility is that the behavior of the unstressed partner toward the stressed mouse disrupts grooming activity. We observed direct contact with the stressed individual that was initiated by the unstressed partner (Fig. 1H). This occurred predominantly in the first $5 \mathrm{~min}$ following return of the stressed individual (Fig. $1 H$ ). During this period, locomotor activity (Fig. $1 \mathrm{Fi}$ ) and grooming activity (Fig. $1 \mathrm{Ci}, \mathrm{Di}$ ) between single-housed and pair-housed female FS mice were not different (locomotion, $p=0.93$, unpaired $t$ test, two-tailed, $t_{(16)}=$ 0.09 ; grooming, $p=0.89$, unpaired $t$ test, two-tailed, $t_{(16)}=$ $0.14)$. These results suggest that the decrease in grooming in pair-housed mice is not because of changes in locomotion or interruption by the unstressed partner.

Next, we conducted experiments in single-housed and pairhoused female mice to ask whether the presence of a partner decreases the synaptic consequences of stress in female mice. Immediately following the 30-min observation period described above, we prepared brain slices from the animals and performed subsequent whole-cell recordings on $\mathrm{CRH}^{\mathrm{PVN}}$ neurons to assess STP. Following HFS of the neuropil, glutamate synapses onto $\mathrm{CRH}^{\mathrm{PVN}}$ neurons from single-housed female mice subjected to
FS show robust STP $(142.0 \pm 8.6 \%, n=11, p=0.0002$ vs baseline, $t_{(10)}=5.6$; Fig. 1Ii,Iii); STP was also observed in pair-housed female FS mice $(116.9 \pm 6.3 \%, n=20, p=0.01$ vs baseline, $t_{(19)}=2.8$; Fig. 1Ji,Jii), but this was significantly reduced when compared with single-housed mice $(p=0.02$, unpaired $t$ test, two-tailed, $t_{(29)}=2.4$; Fig. $1 K$ ). Meanwhile, per animal analysis revealed that STP was present in single-housed FS mice (138.1 $\pm 8.7 \%, N=3, p=0.04$ vs baseline, $t_{(2)}=4.4$; Fig. 1Iiii) but not in pair-housed FS mice $(110.8 \pm 7.1 \%, N=5, p=0.06$ vs baseline, $t_{(4)}=2.6$; Fig. 1Jiii). These findings are consistent with previous findings from our laboratory (Sterley et al., 2018), and provide a useful model to study the neural consequences of social buffering.

\section{VP receptor signaling is required for social buffering of stress-induced STP but not stress-induced grooming or investigative behavior}

Next, we probed whether VP signaling may contribute to the differences in grooming behavior or STP following FS in pairhoused versus single-housed female mice. We hypothesized that VP released in the PVN during social interaction may mediate the reduction in grooming and/or STP. One mouse from a female dyad of littermates received an injection of either the V1aR antagonist SR or vehicle $5 \mathrm{~min}$ before receiving FS (Fig. $2 A)$. The stressed subject was then returned to the homecage with the unstressed partner. We assessed behavior as described above. V1aR antagonism had no effect on time spent grooming following stress (Fig. 2Bi-Cii). Vehicle-injected and SR-injected mice spent a similar amount of time self-grooming (vehicle, $292.2 \pm 45.3 \mathrm{~s}, N=8$; SR, $246.9 \pm 59.5 \mathrm{~s}, N=8 ; p=0.55$, unpaired $t$ test, two-tailed, $t_{(14)}=0.61$; Fig. $2 D$ ). This suggests that $\mathrm{V} 1 \mathrm{aR}$ signaling is not involved in the social buffering of stress-induced grooming.

Next, we tested the effects of V1aR antagonism at the cellular level. We again performed whole-cell recordings on $\mathrm{CRH}^{\mathrm{PVN}}$ neurons from vehicle-injected and SR-injected mice following the 30-min social interaction. STP was observed in $\mathrm{CRH}^{\mathrm{PVN}}$ neurons recorded from stressed female mice that received vehicle injections $\left(119.9 \pm 8.1 \%, n=7, p=0.04\right.$ vs baseline, $t_{(6)}=2.5$; Fig. 2Ei,Eii) and in neurons from mice injected with SR before FS and social interaction $(153.2 \pm 5.7 \%, n=9, p<0.0001$ vs baseline, $t_{(8)}=8.1$; Fig. $2 F i$,Fii). However, per animal analysis showed that STP was present in SR-injected mice (154.4 $\pm 6.4 \%, N=5$, $p=0.004$ vs baseline, $t_{(4)}=5.9$; Fig. 2 Fiii) but was absent in vehicle-injected mice $(119.7 \pm 8.2 \%, N=4, p=0.09$ vs baseline, $t_{(3)}=2.4$; Fig. 2Eiii). Furthermore, STP was significantly greater in SR-injected mice than in vehicle-injected mice $(p=0.004$, unpaired $t$ test, two-tailed, $t_{(14)}=3.5$; Fig. $2 G$ ). These results indicate that the decrease in the synaptic consequences of stress induced by the presence of a partner require VlaRs.

When exposed to a distressed conspecific, rodents engage in unreciprocated investigative behavior directed toward the distressed individual (Knapska et al., 2010; Sterley et al., 2018). One possibility is that this interaction is critical for buffering the synaptic changes in the stressed subject. The total time spent by the unstressed partner spent investigating the stressed subject was unaffected by V1aR blockade (vehicle, $185.1 \pm 14.5 \mathrm{~s}, N=8$; SR, $166.4 \pm 18.8 \mathrm{~s}, N=8 ; p=0.45$, unpaired $t$ test, two-tailed, $t_{(14)}=0.79$; Fig. $3 A$ ). We have previously demonstrated that these investigations target either the head/torso region or the anogenital region of the stressed subject (Sterley et al., 2018). These two behaviors may have different consequences and may differentially contribute to social buffering. We developed a social 
A
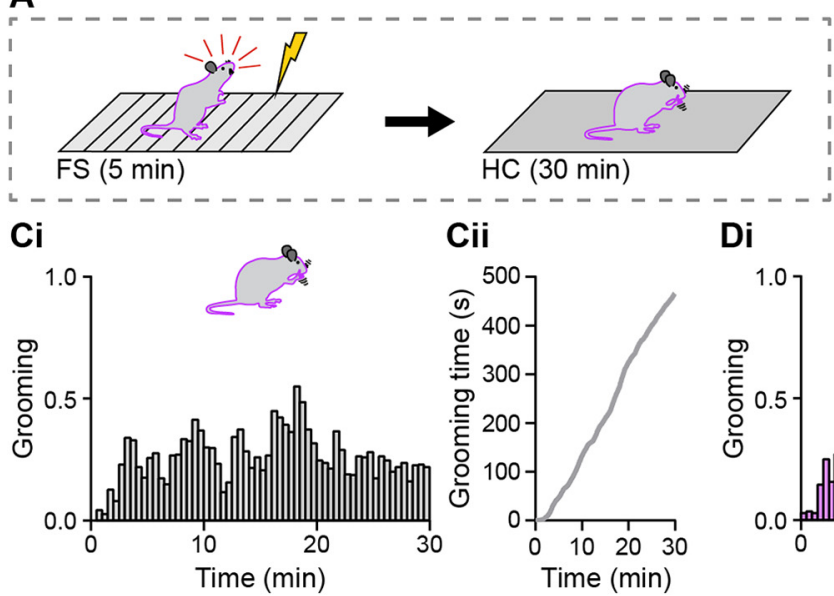

Di
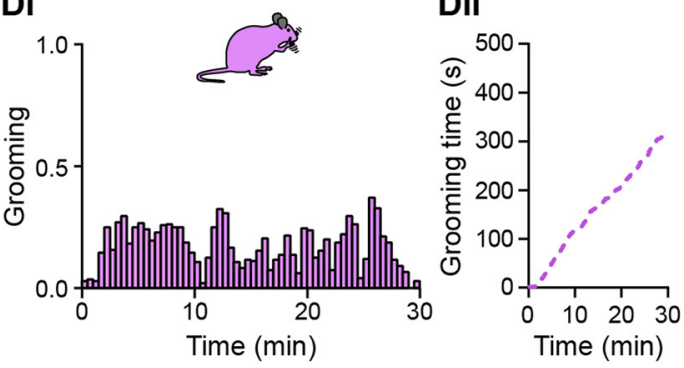

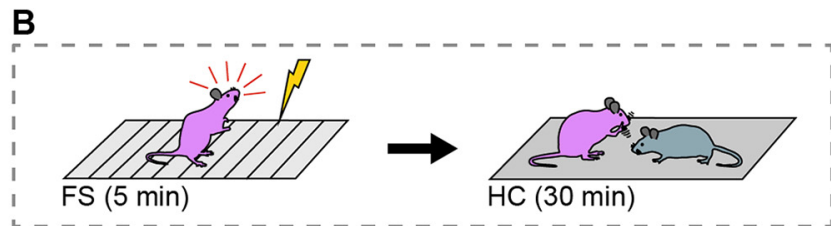

E

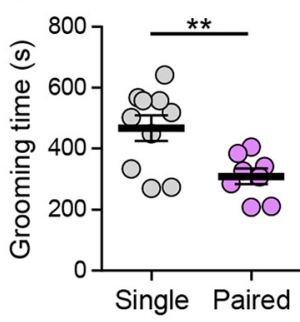

Fi

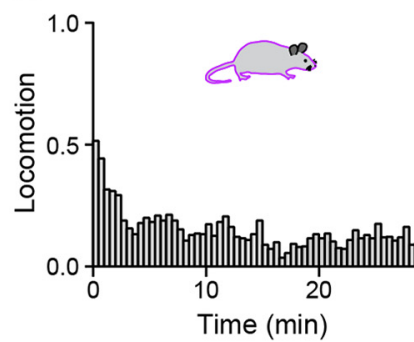

Fii

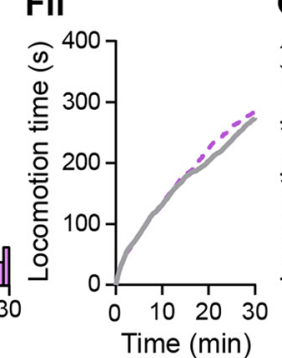

G

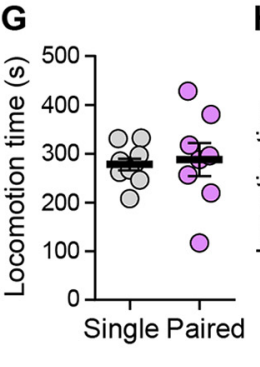

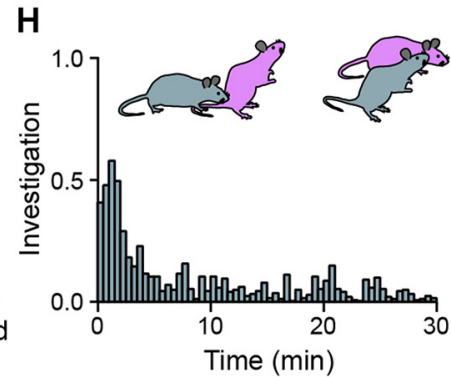

li

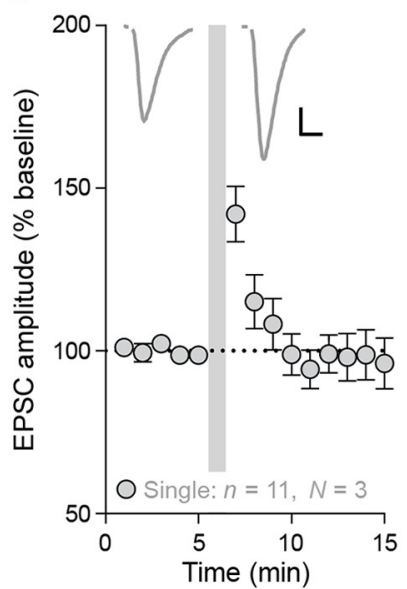

lii Individual cells Ji
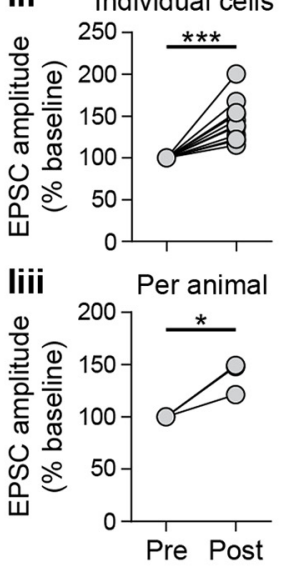

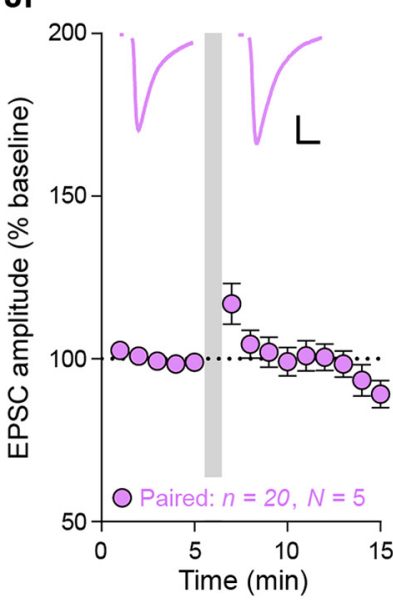

Jii Individual cells
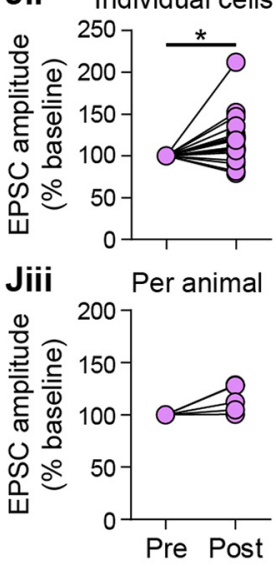

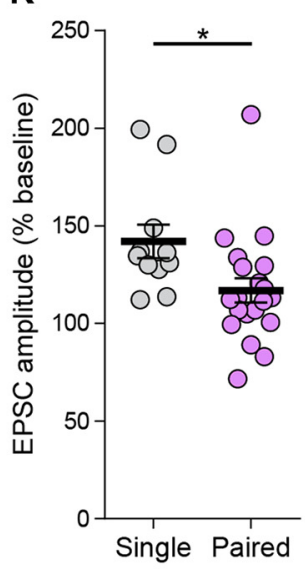

Figure 1. Social interaction reduces stress-induced grooming behavior and STP in CRHPVN neurons. $\boldsymbol{A}$, Single-housed female mice were subjected to the FS protocol $(0.5 \mathrm{~mA}$ for $2 \mathrm{~s}$ every 30 $s$ over $5 \mathrm{~min}$ ) and then returned to the homecage for $30 \mathrm{~min}$. $\boldsymbol{B}$, One mouse from a female dyad of littermates was exposed to FS and returned to its partner in the homecage for 30 min. $\boldsymbol{C}$, Histogram showing the percentage of single-housed FS mice $(N=10$ mice) that exhibited self-grooming behavior during each 30-s bin over the 30-min observation period. Cii, Cumulative graph illustrates the relative grooming of single-housed FS mice. Di, Histogram showing the percentage of pair-housed FS mice ( $N=8$ mice) that exhibited self-grooming behavior during each 30-s bin over the 30-min observation period. Dii, Cumulative graph illustrates the relative grooming of pair-housed FS mice. $E$, Single-housed FS mice engaged in more self-grooming than pair-housed FS mice (single-housed, mean: $467.2 \pm 41.6 \mathrm{~s}, N=10$ mice; pair-housed, mean: $308.6 \pm 25.6 \mathrm{~s}, N=8$ mice; $p=0.008$, unpaired $t$ test, two-tailed, $\left.t_{(16)}=3.1\right)$. Horizontal bars represent the means. Fi, Histograms showing the percentage of single-housed (left; $N=10$ mice) and pair-housed (right; $N=8$ mice) FS mice that exhibited locomotor activity during each 30 $s$ bin over the 30-min observation period. Fii, Cumulative graph illustrates the relative locomotion of single-housed (gray line) and pair-housed (pink line) FS mice. G, Single-housed and pairhoused FS mice spent a similar amount of time engaged in locomotion (single-housed, mean: $277.9 \pm 11.8 \mathrm{~s}, N=10$ mice; pair-housed, mean: $287.9 \pm 33.8 \mathrm{~s}, N=8$ mice; $p=0.77$, unpaired $t$ test, two-tailed, $\left.t_{(16)}=0.30\right)$. Horizontal bars represent the means. $\boldsymbol{H}$, Histogram showing the percentage of unstressed partner mice $(N=8$ mice) that engaged in anogenital or head/torso investigation toward the stressed subject during each 30-s bin over the 30-min observation period. li, EPSCS in CRH ${ }^{\text {PVN }}$ neurons of single-housed FS mice potentiated following HFS (gray bar) relative to baseline. Inset, synaptic currents before and after HFS in single-housed FS mice. lii, STP was present in cells from single-housed FS mice (mean: $142.0 \pm 8.6 \%, n=11$ cells, $p=0.0002$ vs baseline, one-sample $t$ test, two-tailed, $t_{(10)}=5.6$ ). Iiii, STP was present in single-housed FS mice (mean: $138.1 \pm 8.7 \%, N=3$ mice, $p=0.04$ vs baseline, one-sample $t$ test, two-tailed, $\left.t_{(2)}=4.4\right)$. Ji, EPSCs in CRH ${ }^{\mathrm{PVN}}$ neurons of pair-housed FS mice potentiated following HFS (gray bar) relative to baseline. Inset, synaptic currents before and after HFS in pair-housed FS mice. Jii, STP was present in cells from pair-housed FS mice (mean: $116.9 \pm 6.3 \%, n=20$ cells, $p=0.01$ vs baseline, one-sample $t$ test, two-tailed, $t_{(19)}=2.8$ ). Jiii, STP was absent in pairhoused FS mice (mean: $110.8 \pm 7.1 \%, N=5$ mice, $p=0.06$ vs baseline, one-sample $t$ test, two-tailed, $t_{(4)}=2.6$ ). $\boldsymbol{K}$, STP (average ESPC amplitude first minute post-HFS relative to baseline, individual cells shown) was larger in single-housed FS mice than in pair-housed FS mice $\left(p=0.02\right.$, unpaired $t$ test, two-tailed, $\left.t_{(29)}=2.4\right)$. Horizontal bars represent the means. Scale bars (Ii, Ji) represent $5 \mathrm{~ms}$ and $20 \mathrm{pA}$. Inset currents (Ii, Ji) before HFS are scaled to allow for easier comparison after HFS. ${ }^{*} p<0.05,{ }^{* *} p<0.01$, ${ }^{* * *} p<0.001$. Error bars represent \pm SEM. 


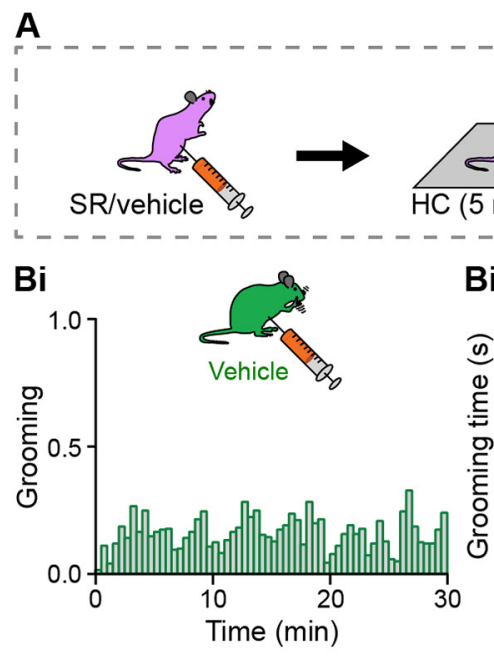

Ei

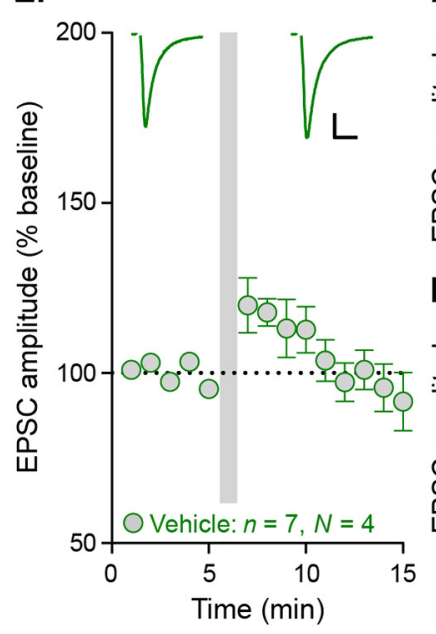

Eii Individual cells Fi
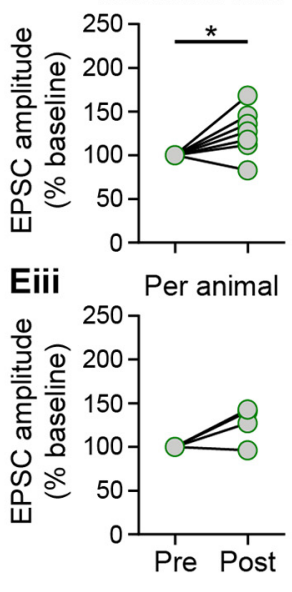

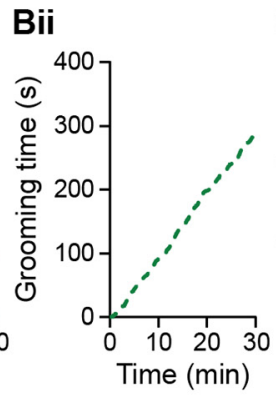

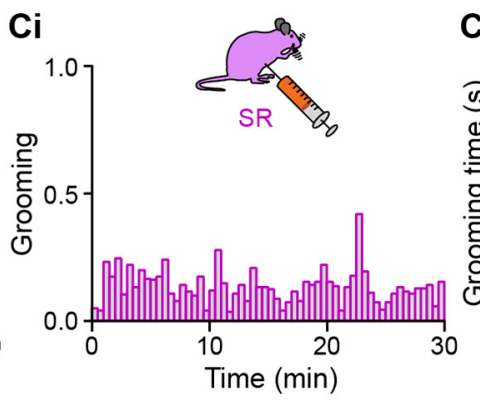

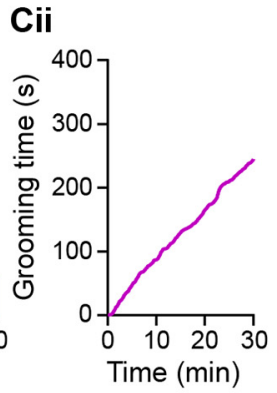

Fii Individual cells $\mathbf{G}$
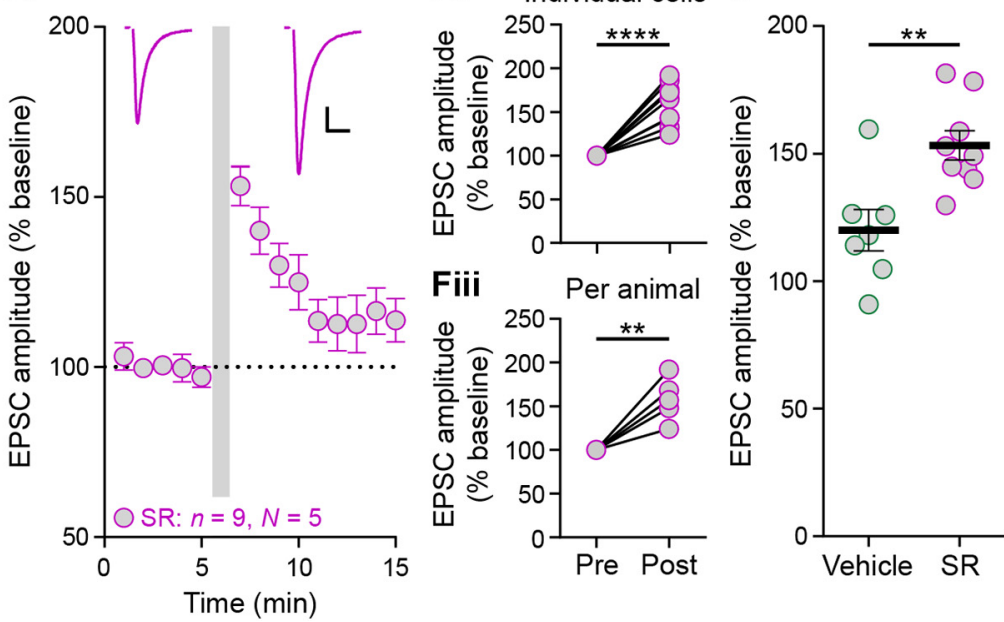

Figure 2. V1aR antagonism prevents social buffering of stress-induced STP but not grooming behavior. $\boldsymbol{A}$, One mouse from a female dyad of littermates was injected intraperitoneally with either the V1aR antagonist SR (2 mg/kg) or vehicle 5 min before FS. Immediately following FS, the mouse was returned to its partner in the homecage for 30 min. Bi, Histogram showing the percentage of vehicle-injected FS mice ( $N=8$ mice) that exhibited self-grooming behavior during each 30-s bin over the 30-min observation period. Bii, Cumulative graph illustrates the relative grooming of vehicle-injected FS mice. Ci, Histogram showing the percentage of SR-injected FS mice ( $N=8$ mice) that exhibited self-grooming behavior during each 30-s bin over the 30-min observation period. Cii, Cumulative graph illustrates the relative grooming of SR-injected FS mice. D, Vehicle-injected and SR-injected FS mice spent a similar amount of time self-grooming (vehicle, mean: $292.2 \pm 45.3 \mathrm{~s}, N=8$ mice; SR, mean: $246.9 \pm 59.5 \mathrm{~s}, N=8$ mice; $p=0.55$, unpaired $t$ test, two-tailed, $\left.t_{(14)}=0.61\right)$. Horizontal bars represent the means. Ei, EPSCs in (RH ${ }^{\text {PVN }}$ neurons of female FS mice injected with vehicle potentiated following HFS (gray bar) relative to baseline. Inset, synaptic currents before and after HFS in vehicle-injected FS mice. Eii, STP was present in cells from vehicle-injected FS mice (mean: $119.9 \pm 8.1 \%, n=7$ cells, $p=0.04$ vs baseline, one-sample $t$ test, two-tailed, $t_{(6)}=2.5$ ). Eiii, STP was absent in vehicle-injected FS mice (mean: $119.7 \pm 8.2 \%, N=4$ mice, $p=0.09$ vs baseline, one-sample $t$ test, two-tailed, $\left.t_{(3)}=2.4\right)$. Fi, EPSCs in CRH ${ }^{\text {PVN }}$ neurons of female FS mice injected with or SR potentiated following HFS (gray bar) relative to baseline. Inset, synaptic currents before and after HFS in SR-injected FS mice. Fii, STP was present in cells from SR-injected FS mice (mean: $153.2 \pm 5.7 \%, n=9$ cells, $p<0.0001$ vs baseline, one-sample $t$ test, two-tailed, $t_{(8)}=8.1$ ). Fiii, STP was present in SR-injected FS mice (mean: $154.4 \pm 6.4 \%, N=5$ mice, $p=0.004$ vs baseline, one-sample $t$ test, two-tailed, $\left.t_{(4)}=5.9\right)$. G, STP (individual cells shown) was larger in SR-injected FS mice than in vehicle-injected FS mice $\left(p=0.004\right.$, unpaired $t$ test, two-tailed, $\left.t_{(14)}=3.5\right)$. Horizontal bars represent the means. Scale bars (Ei, Fi) represent $5 \mathrm{~ms}$ and $20 \mathrm{pA}$. Inset currents (Ei, Fi) before HFS are scaled to allow for easier comparison after HFS. ${ }^{*} p<0.05,{ }^{* *} p<0.01,{ }^{* * * *} p<0.0001$. Error bars represent \pm SEM.

discrimination index to determine whether VlaRs preferentially affect one feature of the investigative behavior (Fig. $3 C$ ). Unstressed partners spent a similar amount of time engaged in both anogenital (vehicle, $90.3 \pm 9.1 \mathrm{~s}, N=8$; SR, $81.9 \pm 11.3 \mathrm{~s}$, $N=8$; Fig. $3 B$ ) and head/torso (vehicle, $94.8 \pm 8.2 \mathrm{~s}, N=8$; SR, $84.5 \pm 8.3 \mathrm{~s}, N=8$; Fig. $3 B$ ) sniffing toward vehicle-injected and SR-injected FS mice (one-way ANOVA, $F_{(3,28)}=0.39, p=0.76$, followed by Sidak's multiple comparisons test; Fig. $3 B$ ). Furthermore, VlaR antagonism did not change the social discrimination index compared with vehicle controls (Fig. $3 C$ ). The duration of locomotion (vehicle, $227.6 \pm 20.6$ s, $N=8$; SR, $227.6 \pm 30.1 \mathrm{~s}, N=8 ; p=0.99$, unpaired $t$ test, two-tailed, $t_{(14)}=0.0009$; Fig. $3 D$ ), surveying (vehicle, $542.0 \pm 40.0 \mathrm{~s}, N=8$; SR, $483.9 \pm 53.4 \mathrm{~s}, N=8 ; p=0.40$, unpaired $t$ test, two-tailed, $t_{(14)}=0.87$; Fig. $3 E$ ), and rearing (vehicle, $62.8 \pm 17.9 \mathrm{~s}, N=8$; SR,
$69.2 \pm 21.8 \mathrm{~s}, \quad N=8 ; p=0.82$, unpaired $t$ test, two-tailed, $t_{(14)}=0.23$; Fig. $3 F$ ) in the stressed subject were also unaffected by V1aR antagonism. Together, these findings suggest that VP signaling is not required for stress-induced grooming in the subject and does not influence locomotion, surveying, or rearing activity. Further, blocking V1aRs in the subject does not affect investigative behaviors by the partner. The absence of behavioral effects suggests that VP effects on STP may occur locally in the PVN and may target synaptic function very specifically.

\section{Ex vivo VP reduces stress-induced STP in females but not males}

Our in vivo experiments above with SR implicate the V1aR in the modulation of stress-induced STP. If inhibition of V1aRs prevents social buffering of STP in $\mathrm{CRH}^{\mathrm{PVN}}$ neurons, then we 
A

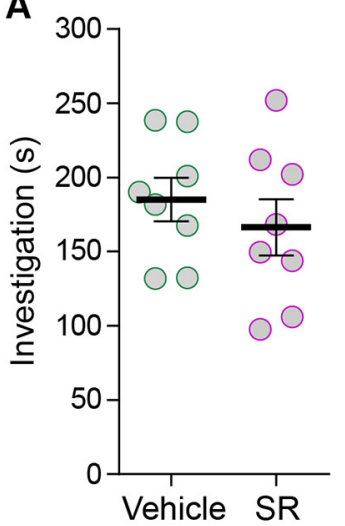

C

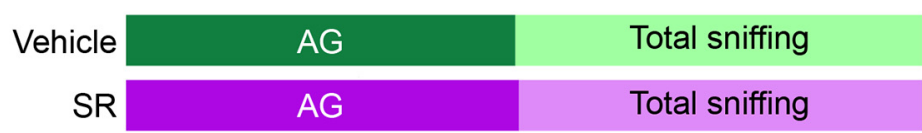

Vehicle

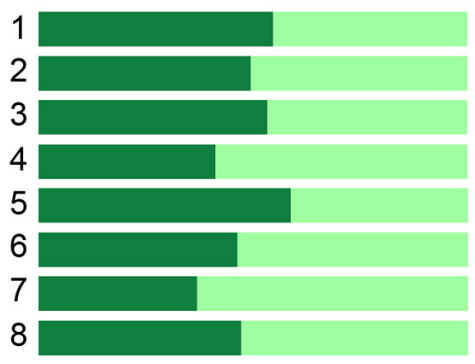

B
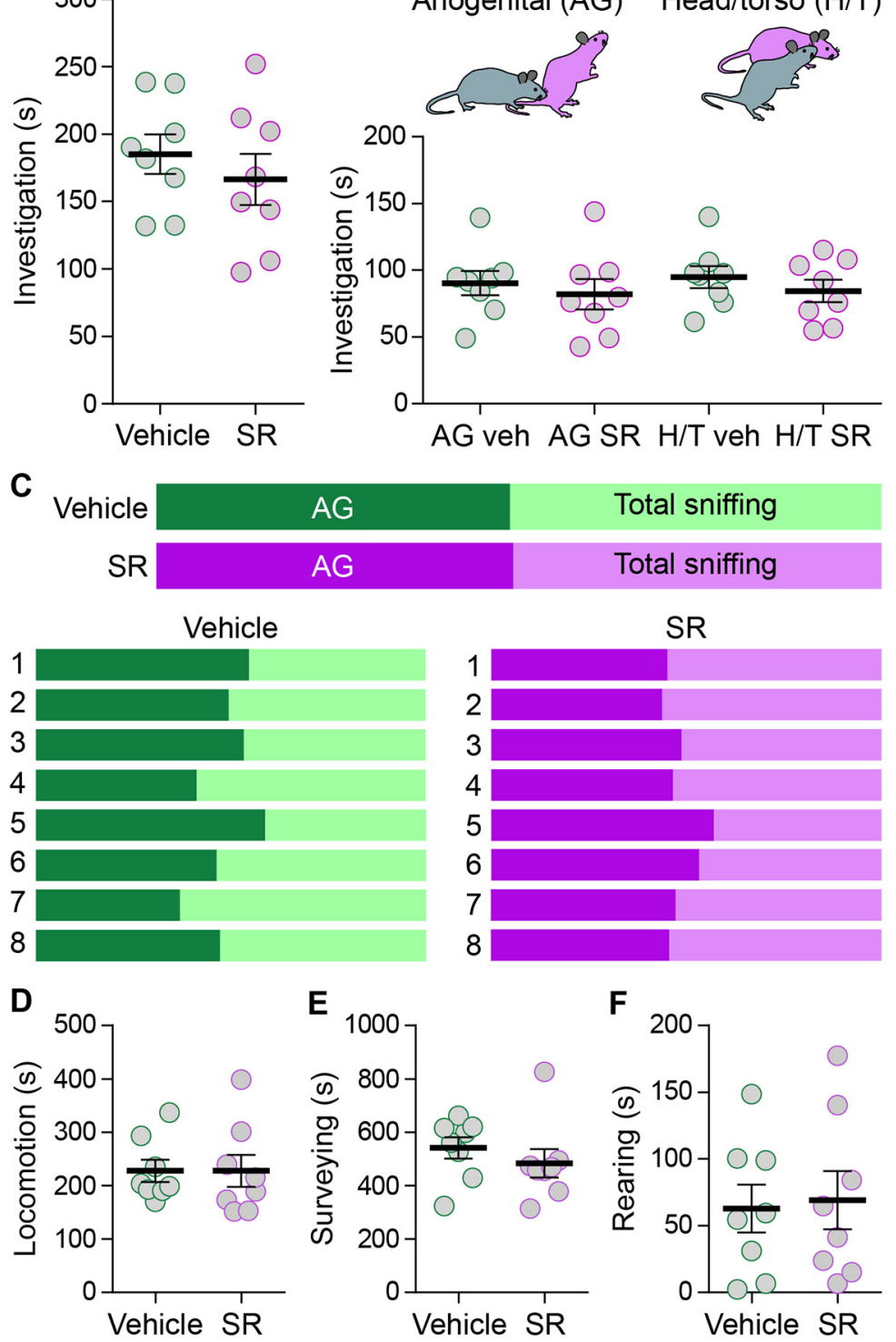

Figure 3. No role for VP receptor signaling in investigative behavior. $A$, Naive mice spent a similar amount of time investigating vehicle-injected and SR-injected FS mice (vehicle, mean: $185.1 \pm 14.5 \mathrm{~S}, N=8$ mice; SR, mean: $166.4 \pm 18.8 \mathrm{~s}, N=8$ mice; $p=0.45$, unpaired $t$ test, two-tailed, $\left.t_{(14)}=0.79\right)$ during the 30 -min observation period. Horizontal bars represent the means. $\boldsymbol{B}$, Naive mice spent a similar amount of time investigating the anogenital region (AG vehicle, mean: $90.3 \pm 9.1 \mathrm{~s}, N=8$ mice; AG SR, mean: $81.9 \pm 11.3 \mathrm{~s}, N=8$ mice; $p=0.76$, one-way ANOVA, $F_{(3,28)}=0.39 ; p=0.99$, followed by Sidak's multiple comparisons test) and head/torso region (H/T vehicle, mean: $94.8 \pm 8.2 \mathrm{~s}, N=8$ mice; H/T SR, mean: $84.5 \pm 8.3 \mathrm{~s}, N=8$ mice; $p=0.97$, Sidak's multiple comparisons test) of SRinjected and vehicle-injected FS mice. Horizontal bars represent the means. C, Color plots (above) show the overall social discrimination indices for naive mice toward their respective vehicle-injected or SR-injected FS partners. Color plots (below) show the social discrimination indices for each individual naive mouse toward their respective FS partner. $\mathbf{D}-\boldsymbol{F}$, The duration of locomotion (vehicle, mean: $227.6 \pm 20.6 \mathrm{~s}, N=8$ mice; SR, mean: $227.6 \pm 30.1 \mathrm{~s}, N=8$ mice; $p=0.99$, unpaired $t$ test, two-tailed, $t_{(14)}=0.0009 ; D$ ), surveying (vehicle, mean: $542.0 \pm 40.0 \mathrm{~s}, N=8$ mice; SR, mean: $483.9 \pm 53.4 \mathrm{~s}, N=8$ mice; $p=0.40$, unpaired $t$ test, two-tailed, $t_{(14)}=0.87 ; \boldsymbol{E}$ ), and rearing (vehicle, mean: $62.8 \pm 17.9 \mathrm{~s}, N=8$ mice; SR, mean: $69.2 \pm 21.8 \mathrm{~s}, N=8$ mice; $p=0.82$, unpaired $t$ test, two-tailed, $t_{(14)}=0.23 ; \boldsymbol{F}$ ) were not different between vehicle-injected and SR-injected FS mice. Horizontal bars represent the means. Error bars represent \pm SEM.

would expect VP itself to decrease STP in these cells in the absence of a partner. To test this, we incubated slices obtained immediately following FS from single-housed stressed female mice in VP (100 nM) for 30 min and examined STP. STP was observed in cells recorded from VP-incubated slices $(120.2 \pm 5.7 \%, n=16$, $p=0.002$ vs baseline, $t_{(15)}=3.7$; Fig. $\left.4 A, B\right)$ and from control aCSF-incubated slices $(152.2 \pm 8.2 \%, n=17, p<0.0001$ vs baseline, $t_{(16)}=5.8$; Fig. $\left.4 A, B\right)$. Per animal analysis gave similar results, with STP being present in VP mice and in aCSF mice (aCSF, $153.8 \pm 9.4 \%, N=14, p=0.0002$ vs baseline, $t_{(13)}=5.1 ; \mathrm{VP}, 117.3 \pm 5.9 \%, N=11, p=$ 0.005 vs baseline, $t_{(10)}=3.5$; Fig. $4 C$ ). However, STP in cells from VP-incubated slices was significantly lower than STP in cells from aCSF-incubated slices $(p=0.007$, one-way ANOVA, $F_{(2,40)}=1.7$; Fig. $\left.4 D\right)$. To confirm our in vivo findings with the V1aR antagonist, we incubated slices from stressed female mice in SR $(10 \mu \mathrm{M})$ for $10 \mathrm{~min}$, followed by incubation in both SR and VP for an additional $30 \mathrm{~min}$. Introduction of SR prevented the VP-induced decrease in STP, as STP in SR-incubated slices was significantly higher than STP from VP-incubated slices $(p=0.04$, Sidak's multiple comparisons test; Fig. $4 D$ ) and was similar to that of aCSFincubated slices $(p=0.69$, Sidak's multiple comparisons test; Fig. $4 D$ ). These findings indicate that activation of $\mathrm{VlaRs}$ by VP reduces stress-induced STP in $\mathrm{CRH}^{\mathrm{PVN}}$ neurons in female mice.

Our initial observations on social buffering of STP revealed that it is a sex-specific effect that occurs exclusively in female mice (Sterley et al., 2018). As such, we determined whether VP also affects STP in a sex-specific manner by repeating the previous experiments in singlehoused male FS mice. STP was observed in $\mathrm{CRH}^{\mathrm{PVN}}$ neurons from slices incubated in aCSF and in VP (aCSF-incubated, 137.1 \pm $7.6 \%, n=12, p=0.0001$ vs baseline, $t_{(11)}=5.9$; VP-incubated, $126.3 \pm 7.9 \%, n=9, p=0.009$ vs baseline, $t_{(8)}=3.4$; Fig. $4 E, F$ ). Per animal analysis revealed that STP was present in both male aCSF and VP mice (aCSF, $138.5 \pm 5.8 \%, N=8$, $p=0.0001$ vs baseline, $t_{(7)}=7.7 ; \mathrm{VP}, 124.9 \pm$ $9.2 \%, N=5, p=0.04$ vs baseline, $t_{(4)}=2.8$; Fig. $4 G)$ Finally, there was no difference in the magnitude of STP between aCSF-incubated and VP-incubated cells from stressed male mice $(p=0.35$, unpaired $t$ test, two-tailed, $t_{(19)}=0.96$; Fig. $4 H$ ). Collectively, these results suggest that VP selectively buffers stressinduced STP in female mice, similar to the effect of social buffering.

\section{VP has limited electrophysiological effects on $\mathrm{CRH}^{\mathrm{PVN}}$ neurons}

To further evaluate the effects of VP on $\mathrm{CRH}^{\mathrm{PVN}}$ neurons, we tested the electrophysiological effects of acute application of VP directly onto $\mathrm{CRH}^{\mathrm{PVN}}$ neurons from stressed female mice. Brain slices were obtained immediately following FS. VP (100 nM) was administered focally to cells via a puff pipette without any blockers in the aCSF. VP had no effect on the firing frequency of action potentials (baseline, $1.0 \pm 0.6 \mathrm{~Hz} ; \mathrm{VP}, 1.1 \pm 0.6 \mathrm{~Hz} ; n=5$, $N=4 ; p=0.20, t_{(4)}=1.5$; Fig. $5 A, B$ ) or membrane potential (baseline, $-48.3 \pm 3.7 \mathrm{mV}$; VP, $-48.6 \pm 4.0 \mathrm{mV} ; n=5, N=4 ; p=0.63$, 
A

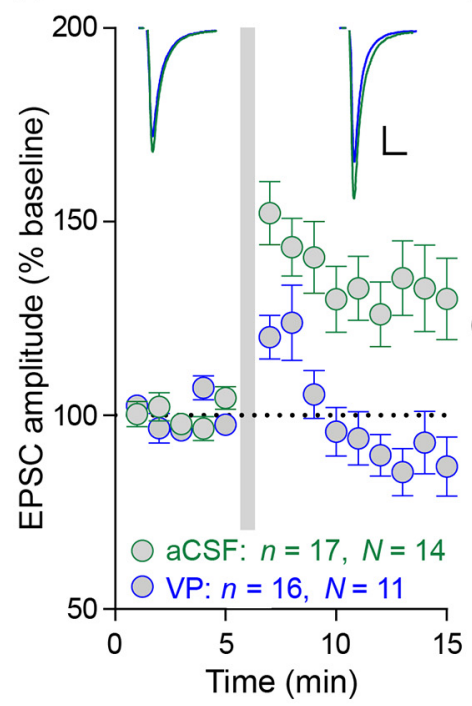

E

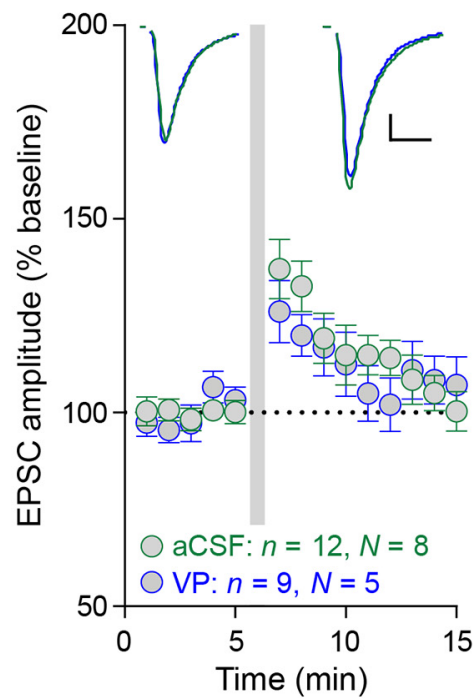

B

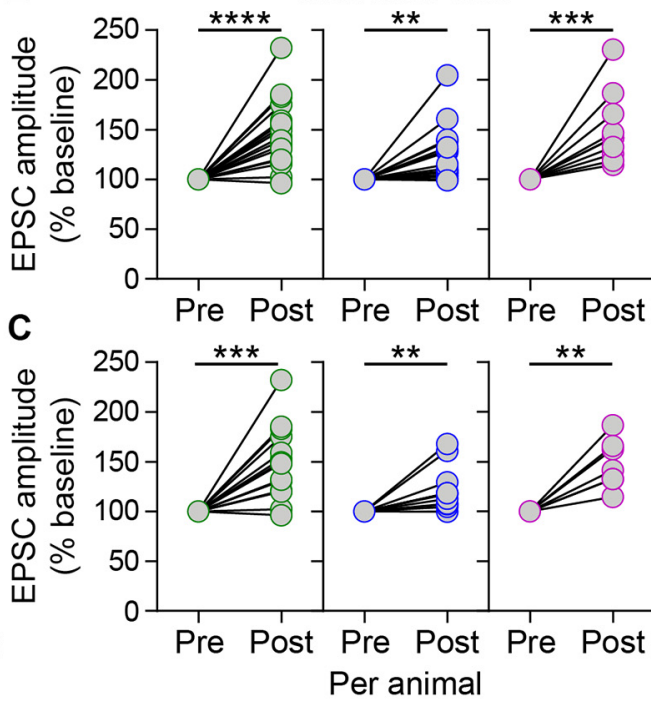

$\mathbf{F}$

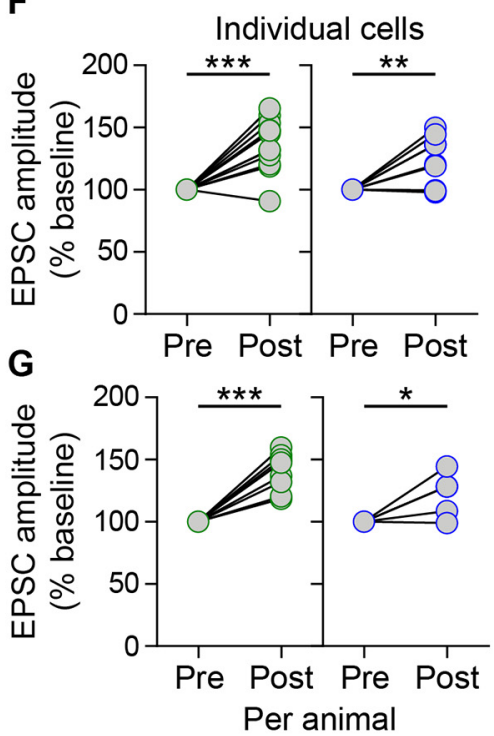

D

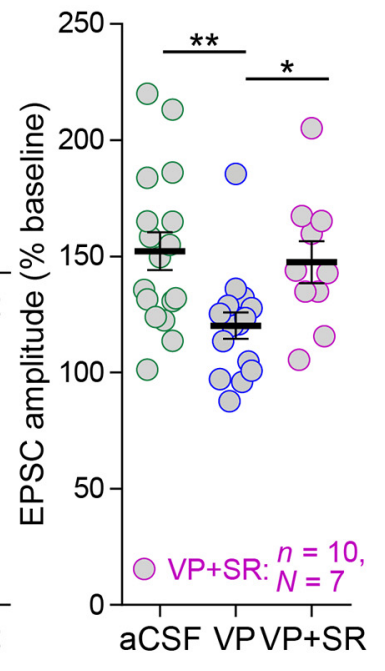

H

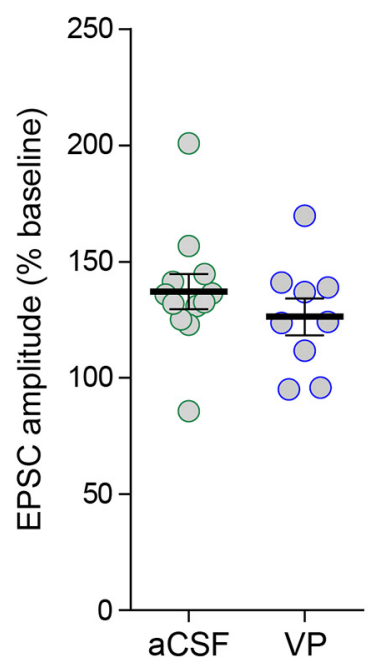

Figure 4. VP reduces STP in CRH ${ }^{\mathrm{PVN}}$ neurons from females but not males. $\boldsymbol{A}$, EPSCS in CRH ${ }^{\mathrm{PVN}}$ neurons potentiated following HFS (gray bar) relative to baseline in aCSF control slices (green outline) and in VP-incubated slices (blue outline) from single-housed female mice stressed with FS. Inset, synaptic currents before and after HFS in aCSF-incubated and VP-incubated cells. $\boldsymbol{B}$, STP was present in aCSF-incubated cells (mean: $152.2 \pm 8.2 \%, n=17$ cells, $p<0.0001$ vs baseline, one-sample $t$ test, two-tailed, $t_{(16)}=5.8$ ), in VP-incubated cells (mean: $120.2 \pm 5.7 \%$, $n=16$ cells, $p=0.002$ vs baseline, one-sample $t$ test, two-tailed, $t_{(15)}=3.7$ ), and in SR+VP-incubated cells (pink outline, mean: $147.5 \pm 9.0 \%, n=10$ cells, $p=0.0007$ vs baseline, one-sample $t$ test, two-tailed). C, STP was present female aCSF mice (mean: $153.8 \pm 9.4 \%, N=14$ mice, $p=0.0002$ vs baseline, one-sample $t$ test, two-tailed, $\left.t_{(13)}=5.1\right)$, in female VP mice (mean: $117.3 \pm 5.9 \%, N=11$ mice, $p=0.005$ vs baseline, one-sample $t$ test, two-tailed, $t_{(10)}=3.5$ ), and in female SR+VP mice (mean: $146.8 \pm 8.9 \%, N=7$ mice, $p=0.001$ vs baseline, one-sample $t$ test, two-tailed). $\boldsymbol{D}$, STP (individual cells shown) was larger in aCSF-incubated cells ( $p=0.007$, one-way ANOVA, $F_{(2,40)}=1.7 ; p=0.008$, followed by Sidak's multiple comparisons test) and in SR+VP-incubated cells ( $p=0.04$, Sidak's multiple comparisons test) than in VP-incubated cells. Horizontal bars represent the means. $E$, EPSCs in CRP ${ }^{\mathrm{PVN}}$ neurons potentiated following HFS (gray bar) relative to baseline in aCSF control slices (green outline) and in VP-incubated slices (blue outline) from single-housed male mice stressed with FS. Inset, synaptic currents before and after HFS in aCSF-incubated and VP-incubated cells. $\boldsymbol{F}$, STP was present in aCSF-incubated cells (mean: $137.1 \pm 7.6 \%, n=12$ cells, $p=0.0001$ vs baseline, one-sample $t$ test, two-tailed, $t_{(11)}=5.9$ ) and in VPincubated cells (mean: $126.3 \pm 7.9 \%, n=9$ cells, $p=0.009$ vs baseline, one-sample $t$ test, two-tailed, $\left.t_{(8)}=3.4\right)$. G, STP was present in male aCSF mice (mean: $138.5 \pm 5.8 \%, N=8$ mice, $p=0.0001$ vs baseline, one-sample $t$ test, two-tailed, $t_{(7)}=7.7$ ) and in male VP mice (mean: $124.9 \pm 9.2 \%, N=5$ mice, $p=0.04$ vs baseline, one-sample $t$ test, two-tailed, $t_{(4)}=2.8$ ). $\boldsymbol{H}$, STP (individual cells shown) in aCSF-incubated cells was similar to that in VP-incubated cells $\left(p=0.35\right.$, unpaired $t$ test, two-tailed, $\left.t_{(19)}=0.96\right)$. Horizontal bars represent the means. Scale bars $(A, E)$ represent $5 \mathrm{~ms}$ and 20 pA. Inset currents $(A, E)$ before HFS are scaled to allow for easier comparison after HFS. ${ }^{*} p<0.05,{ }^{* *} p<0.01,{ }^{* * *} p<0.001,{ }^{* * * *} p<0.0001$. Error bars represent \pm SEM.

$t_{(4)}=0.52$; Fig. $\left.5 A, C\right)$. Next, we analyzed the effects of VP on sEPSCs in CRH ${ }^{\mathrm{PVN}}$ neurons following bath application of the peptide in aCSF containing picrotoxin. Similar to the above current clamp experiment, VP (100 nM) had no effect on the frequency (baseline, $7.2 \pm 1.8 \mathrm{~Hz} ; \mathrm{VP}, 6.5 \pm 1.4 \mathrm{~Hz}$; $n=5, N=5 ; p=0.53, t_{(4)}=0.68$; Fig. $\left.5 D, E\right)$ or amplitude (baseline, $27.6 \pm 4.8 \mathrm{pA} ; \mathrm{VP}, 28.3 \pm 5.2 \mathrm{pA} ; n=5, N=5$; $p=0.43, t_{(4)}=0.88$; Fig. $\left.5 D, F\right)$ of sEPSCs. Taken together, these observations suggest that the electrophysiological effects of VP on $\mathrm{CRH}^{\mathrm{PVN}}$ neurons following acute stress are specific to synaptic metaplasticity.

\section{VP acts on $\mathrm{CRH}^{\mathrm{PVN}}$ neurons to decrease the AMPA/NMDA} ratio

In parvocellular neurosecretory cells in the PVN of male rats, a stress-induced decrease in NMDAR function is obligatory for the induction of STP (Kuzmiski et al., 2010). This occurs in response to immobilization, predator odor or swim stress. If a 
A
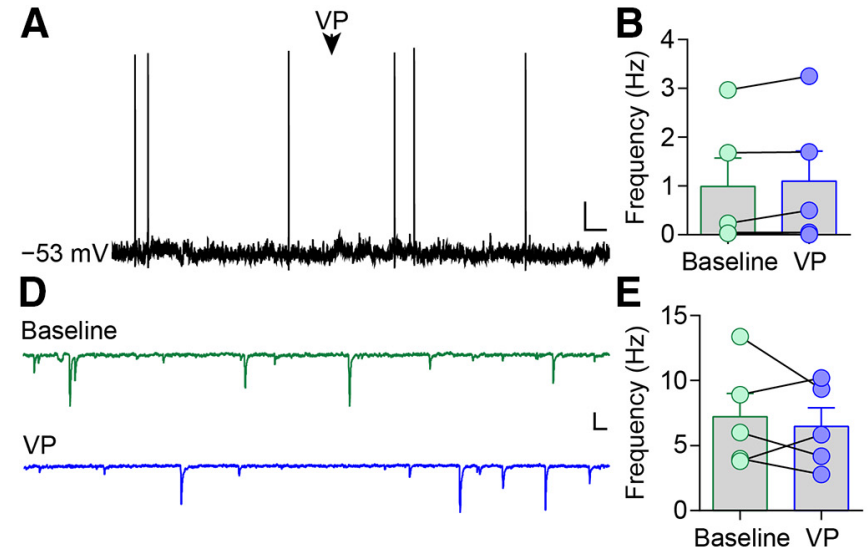

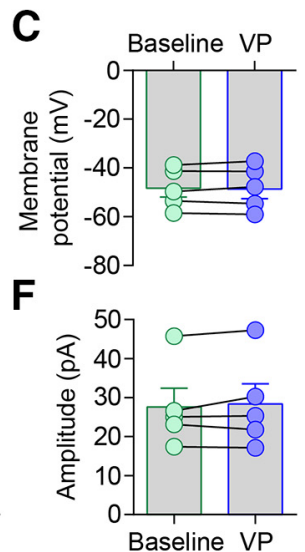

Figure 5. VP has limited electrophysiological effects on CRH ${ }^{\mathrm{PVN}}$ neurons following stress. $\boldsymbol{A}$, Representative current-clamp recording from a $\mathrm{CRH}^{\mathrm{PVN}}$ neuron from a female mouse showing that a VP puff (100 nM, arrowhead) had no effect on the membrane potential or firing. $B$, C, Summary data of the effects of VP on firing frequency (baseline, mean: $1.0 \pm 0.6 \mathrm{~Hz}$; VP, mean: $1.1 \pm 0.6 \mathrm{~Hz} ; n=5$ cells, $N=4$ mice; $p=0.20, t_{(4)}=1.5 ; B$ ) and membrane potential (baseline, mean: $48.3 \pm 3.7 \mathrm{mV} ; \mathrm{VP}$, mean: $-48.6 \pm 4.0 \mathrm{mV} ; n=5$ cells, $N=4$ mice; $\left.p=0.63, t_{(4)}=0.52 ; \mathrm{C}\right)$ of $\mathrm{CRH}^{\mathrm{PVN}}$ neurons from female FS mice. $\boldsymbol{D}$, Representative voltage-clamp traces from a $\mathrm{CRH}^{\mathrm{PVN}}$ neuron from a female mouse showing that bath application of VP (100 nM) had no effect on the frequency or amplitude of sEPSCs. $E, F$, Summary data of the effects of VP on the frequency (baseline, mean: $7.2 \pm 1.8 \mathrm{~Hz}$; VP, mean: $6.5 \pm 1.4 \mathrm{~Hz} ; n=5$ cells, $N=5$ mice; $p=0.53, t_{(4)}=0.68 ; E$ ) and amplitude (baseline, mean: $27.6 \pm 4.8 \mathrm{pA}$; VP, mean: $28.3 \pm 5.2 \mathrm{pA} ; n=5$ cells, $N=5$ mice; $\left.p=0.43, t_{(4)}=0.88 ; \boldsymbol{F}\right)$ of sEPSCs in CRH ${ }^{\text {PVN }}$ neurons. Scale bars $(\boldsymbol{A})$ represent $5 \mathrm{~s}$ and $15 \mathrm{mV}$. Scale bars $(\boldsymbol{D})$ represent $15 \mathrm{~ms}$ and $20 \mathrm{pA}$. Error bars represent \pm SEM. on $\mathrm{CRH}^{\mathrm{PVN}}$ neurons, causing an increase in NMDAR-mediated currents. This VPmediated increase in NMDAR function may be part of the mechanism through which STP is reduced.

\section{Discussion}

Our results demonstrate that the presence of a partner buffers the synaptic consequences of stress, and decreases stressinduced grooming behavior in female mice subjected to FS stress. VlaRs are required for social buffering of the synaptic changes but not the grooming behavior. These synaptic actions rely on V1aRs on $\mathrm{CRH}^{\mathrm{PVN}}$ neurons that reduce AMPA/ NMDA and decrease STP. Finally, the local effects of VP on STP are sex specific, with no local effects on glutamate plasticity in males. These findings establish a critical role for local VP signaling in the PVN in female mice that results in synaptic buffering after stress and social interaction.

Although $\mathrm{CRH}^{\mathrm{PVN}}$ neurons are traditionally viewed as neuroendocrine cells similar process is required for STP induction in $\mathrm{CRH}^{\mathrm{PVN}}$ neurons in female mice in response to FS, then buffering of STP may rely on an increase in NMDAR-mediated currents and/or a decrease in AMPAR-mediated currents that restore the AMPA/NMDA ratio toward basal levels. To determine whether VP modulates NMDARmediated and/or AMPAR-mediated currents, we recorded the AMPA/NMDA ratio in $\mathrm{CRH}^{\mathrm{PVN}}$ neurons from stressed female mice following VP incubation of slices obtained immediately after FS. The AMPA/NMDA ratio was significantly reduced in cells from VP-incubated slices compared with cells from aCSF control slices (aCSF, $3.8 \pm 0.5, n=9$; VP-incubated, $2.2 \pm 0.4, n=5 ; p=0.04, t_{(12)}=2.3$; Fig. $6 A$ ). We also recorded the AMPA/NMDA ratio before and after bath application of VP (100 nM) to cells from female FS mice. Acute VP application significantly reduced the AMPA/NMDA ratio within these cells (baseline, $3.3 \pm 0.7$; $\mathrm{VP}, 2.4 \pm 0.5 ; n=5, p=0.01, t_{(4)}=4.1$; Fig. $\left.6 B\right)$. There was no difference in the AMPA/NMDA ratio between VP incubation and acute VP application (VP-incubated, $2.2 \pm 0.4$, $n=5$; acute VP, $2.4 \pm 0.5, n=5 ; p=0.66, t_{(8)}=0.46$; Fig. $\left.6 C\right)$. Next, we isolated NMDAR-mediated currents in $\mathrm{CRH}^{\mathrm{PVN}}$ neurons from single-housed female FS mice by the addition of DNQX to the aCSF. Acute VP (100 nM) application increased the NMDA current $\left(136.8 \pm 12.2 \%, n=11, p=0.01\right.$ vs baseline, $t_{(10)}=3.2$; Fig. 6D).

Our previous experiments with the $\mathrm{VlaR}$ antagonist suggest that VP is acting on this receptor to produce its effects on STP. It is not clear whether VP acts directly through V1aRs on $\mathrm{CRH}^{\mathrm{PVN}}$ neurons themselves, or, as recently shown, indirectly through receptors on astrocytes (Haam et al., 2014). To determine the synaptic location of the V1aRs that mediate the reduction in the AMPA/NMDA ratio, we included GDP $\beta$ S ( $1 \mathrm{~mm}$ ) in the patch pipette to disrupt G-protein-mediated signaling in postsynaptic $\mathrm{CRH}^{\mathrm{PVN}}$ neurons and repeated the experiment described above. Acute VP application had no effect on the AMPA/NMDA ratio in cells loaded with GDP $\beta$ S (baseline, $2.9 \pm 0.4 ; \mathrm{VP}, 2.7 \pm 0.3, n=5 ; p=0.51, t_{(4)}=$ 0.72 ; Fig. $6 E$ ). Together, these data suggest that VP acts on V1aRs essential for HPA axis activation, increasing evidence has implicated these neurons in the control of stress-related behaviors (Füzesi et al., 2016; Zhang et al., 2017; Sterley et al., 2018; Daviu et al., 2020). We explored stress-induced grooming in females, an action that rodents initiate following stress (van Erp et al., 1994; Kruk et al., 1998) and one that has been shown to be mediated by collateral projections of $\mathrm{CRH}^{\mathrm{PVN}}$ neurons to the lateral hypothalamus (Füzesi et al., 2016). We show that the presence of a partner reduces the time spent engaged in self-grooming following stress. Our initial hypothesis, that VP release in the PVN may mediate this social buffering of grooming, was rejected by our observations that $\mathrm{V} 1 \mathrm{aR}$ inhibition had no effect on this behavior. This observation is consistent with previous findings that intracerebroventricular (ICV) administration of a selective $\mathrm{V}$ laR antagonist does not reduce novelty-induced grooming in rats (Drago et al., 1997). Furthermore, although V1aR inhibition can suppress grooming induced by central VP administration, antagonists for this receptor are unable to reduce grooming induced by other peptides (Meisenberg and Simmons, 1987), suggesting the inhibitory effect on grooming is specific to that mediated by VP. In addition to the lack of an effect on self-grooming, V1aR inhibition did not influence investigative behavior of the naive partner toward the stressed individual as assessed by sniffing times and our social discrimination index. This is in agreement with our previous findings that return of the stressed individual to the homecage is likely sufficient to trigger investigative sniffing behavior and that this behavior is independent of $\mathrm{CRH}^{\mathrm{PVN}}$ neuron activity in that stressed animal (Sterley et al., 2018).

When we compared the activity at glutamatergic synapses on $\mathrm{CRH}^{\mathrm{PVN}}$ neurons, we observed a reduction in stress-induced STP in pair-housed female mice versus single-housed females. Unlike self-grooming, this social buffering of STP was dependent on V1aR signaling, as inhibition of this receptor produced a robust STP that was similar to single-housed animals. Although $\mathrm{CRH}^{\mathrm{PVN}}$ neuron activation can drive grooming behavior (Füzesi et al., 2016), our observed increase in STP but lack of an effect on 

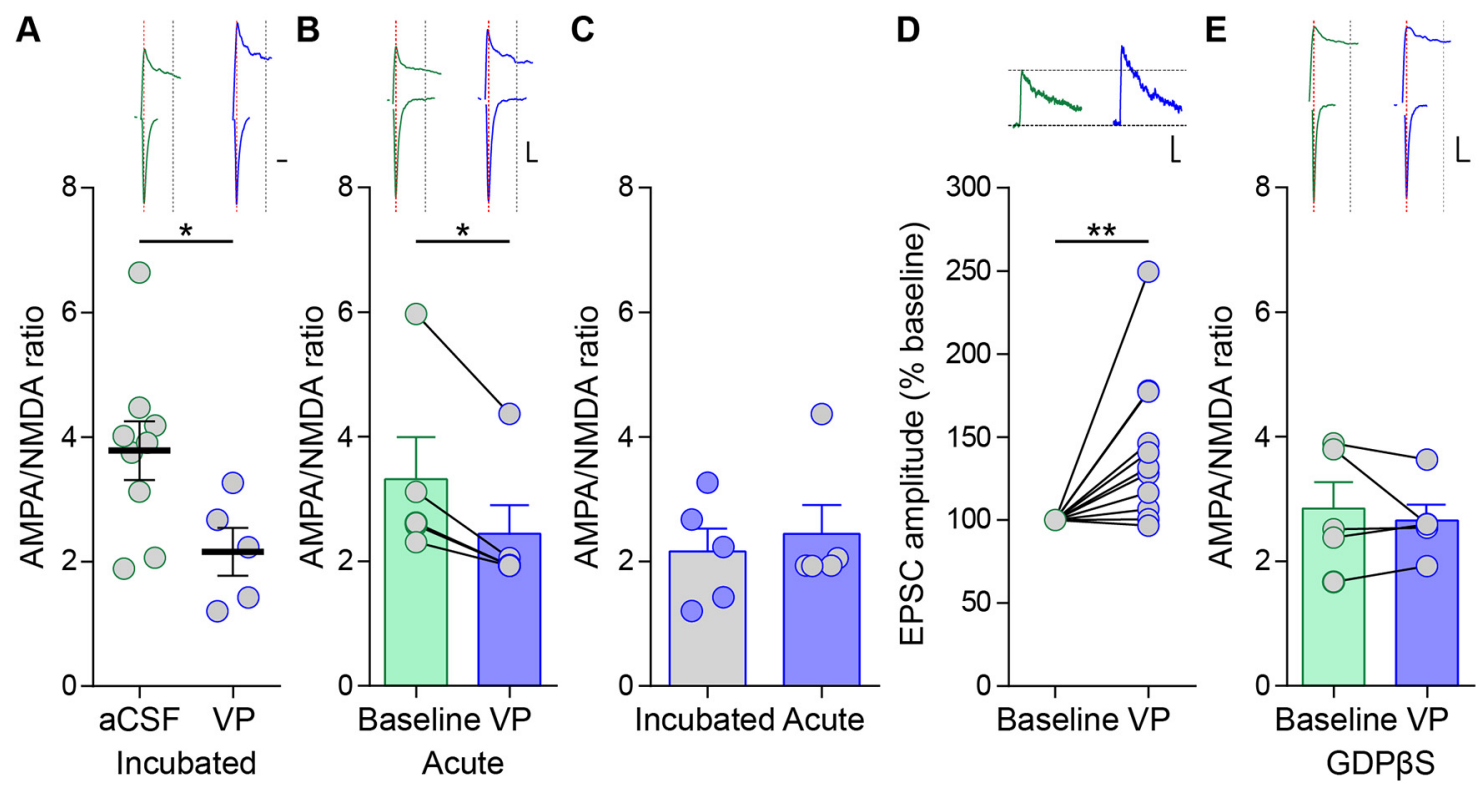

Figure 6. VP decreases the AMPA/NMDA ratio in CRH ${ }^{\mathrm{PVN}}$ neurons. $A$, The AMPA/NMDA ratio (individual cells shown with currents scaled to AMPA current in aCSF) was larger in aCSF-incubated cells (green outline, mean: $3.8 \pm 0.5, n=9$ cells, $N=6$ mice) than in VP-incubated cells (blue outline, mean: $2.2 \pm 0.4, n=5$ cells, $N=3$ mice; $p=0.04$, unpaired $t$ test, two-tailed, $\left.t_{(12)}=2.3\right)$ from female mice stressed with FS. Horizontal bars represent the means. Inset, AMPA and NMDA currents from aCSF-incubated and VP-incubated cells. $B$, The AMPA/NMDA ratio was decreased following acute application of $100 \mathrm{~nm} \mathrm{VP}$ within the same cells (baseline, mean: $3.3 \pm 0.7 ; \mathrm{VP}$, mean: $2.4 \pm 0.5, n=5$ cells; $p=0.01$, paired $t$ test, two-tailed, $\left.t_{(4)}=4.1\right)$. Inset, AMPA and NMDA currents from the same cell before and after VP application. $C$, The AMPA/NMDA ratio was similar between VP-incubated cells and cells following acute VP application (VPincubated, mean: $2.2 \pm 0.4, n=5$; acute VP, mean: $2.4 \pm 0.5, n=5 ; p=0.66$, unpaired $t$ test, two-tailed, $t_{(8)}=0.46$ ). $D$, Acute VP application increased isolated NMDA currents (mean: $136.8 \pm 12.2 \%, n=11$ cells, $p=0.01$ vs baseline, paired $t$ test, two-tailed, $t_{(10)}=3.2$. Inset, traces show the NMDA current in the same cell before and after VP application. $\boldsymbol{E}$, Acute VP application had no effect on the AMPA/NMDA ratio in cells loaded with $1 \mathrm{~mm} \mathrm{GDP} \beta$ S (baseline, mean: $2.9 \pm 0.4 ; \mathrm{VP}$, mean: $2.7 \pm 0.3, n=5$ cells; $p=0.51$, paired $t$ test, two-tailed, $t_{(4)}=0.72$ ). Inset, AMPA and NMDA currents before and after VP application in a cell loaded with GDP $\beta$ S. Scale bars $(\boldsymbol{A}, \boldsymbol{B}, \boldsymbol{D}, \boldsymbol{E})$ represent $5 \mathrm{~ms}$ and $20 \mathrm{pA}$. Red dotted lines $(\boldsymbol{A}, \boldsymbol{B}, \boldsymbol{E})$ represent the AMPA current measurement. Gray dotted lines $(\boldsymbol{A}, \boldsymbol{B}, \boldsymbol{E})$ represent the NMDA current measurement. ${ }^{*} p<0.05,{ }^{* *} p<0.01$. Error bars represent \pm SEM.

grooming following V1aR inhibition suggests that stress-induced grooming is independent of STP in these neurons. Furthermore, as STP decays within minutes, it is unlikely to be necessary for the maintenance of grooming behavior throughout the observation period. Thus, effects of VP on social buffering are likely localized to the synapse. Although VP is a well-known ACTH secretagogue at the median eminence (Gillies et al., 1982; Antoni, 1993), several studies have demonstrated an inhibitory effect of VP on the HPA axis at the level of the hypothalamus. ICV administration of VP into the third ventricle produces a concentration-dependent decrease in immunoreactive CRH secretion into the hypophysial portal circulation (Plotsky et al., 1984). Social defeat and forced swimming both cause intra-PVN release of VP that is dissociated from peripheral release and likely exerts an inhibitory effect on ACTH secretion (Wotjak et al., 1996, 1998). Additionally, Wotjak et al. (1996) observed no significant effect of a V1 antagonist in the PVN on anxiety-related behavior, consistent with our lack of an effect of SR on stress-induced grooming.

While hybridization histochemistry experiments have revealed V1aRs localized to the parvocellular PVN (Ostrowski et al., 1994), previous studies have demonstrated a retrograde neuronal-glial autoregulatory circuit within the PVN mediated by dendritically-released VP (Haam et al., 2014; Chen et al., 2019), implicating astrocytic V1aRs in local VP signaling. Our finding that loading $\mathrm{CRH}^{\mathrm{PVN}}$ neurons with GDP $\beta$ S blocks the effects of VP on the AMPA/NMDA ratio suggests that VP mediates its cellular effects through receptors located on $\mathrm{CRH}^{\mathrm{PVN}}$ neurons themselves. This result, plus the observed increase in NMDARmediated currents following VP administration, indicates the potential mechanism underlying the VP-mediated reduction in STP. As depression of NMDARs is required for STP (Kuzmiski et al., 2010), our observations indicate a restoration of NMDAR function that facilitates the reduction in STP.

We also probed for the effects of VP on STP in males. Unlike our results from female mice, we observed no change in STP following VP incubation of slices from male animals. Although we did not explore the mechanism underlying these sex differences, it is unlikely that differences in VP release between males and females account for this sexually dimorphic effect since VP incubation did not change STP in males. Instead, these experiments suggest a difference that is downstream of VP release, but does not completely negate the possibility of a concurrent upstream difference. Acute stress exposure during different periods in the lifespan can differentially influence HPA axis function. In rodents, delayed maturation of glucocorticoid negative feedback mechanisms causes extended corticosterone release in prepubertal animals (McCormick and Mathews, 2007). While pubertal changes in sex hormones can have profound influences on the developing brain, differences in HPA reactivity appear to be independent of changes in circulating sex hormones (Klein and Romeo, 2013). As we have reliably observed STP that is unaltered up to $24 \mathrm{~h}$ following stress exposure in mice up to early adulthood (Sterley et al., 2018), we do not predict an age-related effect in our mice. However, one possible explanation relates to V1aR desensitization. Like many GPCRs, the V1aR undergoes agonistinduced phosphorylation by G-protein-coupled receptor kinases, which promotes $\beta$-arrestin association and a subsequent internalization of the receptor (Innamorati et al., 1998, 1999; BowenPidgeon et al., 2001). While no studies have reported sex differences in this process for V1aRs, an example of this does exist for $\mathrm{CRH}$ receptor 1 (CRHR1) in locus coeruleus neurons. In male rats, acute swim stress causes $\beta$-arrestin 2 to associate with CRHR1 and leads to internalization of the receptor; however, in 
females, this stress-induced internalization is impaired because of diminished CRHR1- $\beta$-arrestin 2 association, which renders these neurons more sensitive to CRH (Bangasser et al., 2010). It is possible that a similar sex difference exists for V1aRs in $\mathrm{CRH}^{\mathrm{PVN}}$ neurons.

Sex differences in VP signaling have also been attributed to polymorphisms in repetitive DNA sequences, or microsatellites, in the $5^{\prime}$ regulatory region of the gene encoding the $\mathrm{V} 1 \mathrm{aR}$, Avpr1a. Of particular interest are two highly polymorphic microsatellites in the promotor region, RS1 and RS3. Microsatellite length predicts intraspecific variation in $\mathrm{V} 1 \mathrm{aR}$ expression and social behavior in male prairie voles, with long-allele males displaying increased social investigation and bonding behavior compared with short-allele males (Hammock and Young, 2005). Both short-allele and long-allele males show robust differences in $\mathrm{V} 1 \mathrm{aR}$ binding in several brain regions (Hammock and Young, 2005). In humans, longer RS3 repeat length is associated with increased altruistic behavior and higher V1aR mRNA levels in the hippocampus (Knafo et al., 2008). Polymorphisms in Avprla in the PVN that lead to changes in receptor expression may account for our observed sex differences in the effects of VP on $\mathrm{STP}$ in $\mathrm{CRH}^{\mathrm{PVN}}$ neurons. Future experiments using genetic analysis are required to confirm the existence of these polymorphisms in the PVN of mice.

The fundamental question that remains is what causes VP release in the PVN during social buffering. One intriguing mechanism is through the OR37 subfamily, part of an olfactory subsystem that has been previously implicated in stress buffering. Endogenous ligands for OR37 receptors, which are found in bodily secretions from mice, reduce c-Fos expression in $\mathrm{CRH}^{\mathrm{PVN}}$ neurons following exposure to a novel environment (Klein et al., 2015). In humans, exposure to undetected hexadecanal, a ligand for OR37 receptors, reduces the acoustic startle response in typically-developed adults but has no effect in cognitively-able adult participants with autism spectrum disorder (Endevelt-Shapira et al., 2018). The mitral cells of OR37 glomeruli project specifically to VPergic cells in the PVN (Bader et al., 2012). As both magnocellular and parvocellular VP neurons are capable of dendritic release of VP (Ludwig, 1998), activation of the OR37 subsystem may be the source that initiates VP release in the PVN. However, future experiments are required to confirm an involvement of this subsystem in VP-mediated social buffering.

Several stress-related psychiatric disorders, including posttraumatic stress disorder, anxiety, and depression, are associated with altered urinary and plasma VP levels (van Londen et al., 1997; de Kloet et al., 2008; Marshall, 2013), suggesting dysfunction of the VP system. However, as somatodendritic release of VP can occur independently of peptide release from the axon terminal (Wotjak et al., 1998), the translational implications of our findings on local VP signaling in the PVN remain to be determined.

\section{References}

Antoni FA (1993) Vasopressinergic control of pituitary adrenocorticotropin secretion comes of age. Front Neuroendocrinol 14:76-122.

Archer J (2009) Does sexual selection explain human sex differences in aggression? Behav Brain Sci 32:249-266.

Bader A, Klein B, Breer H, Strotmann J (2012) Connectivity from OR37 expressing olfactory sensory neurons to distinct cell types in the hypothalamus. Front Neural Circuits 6:84.

Bangasser DA, Curtis A, Reyes BAS, Bethea TT, Parastatidis I, Ischiropoulos H, Van Bockstaele EJ, Valentino RJ (2010) Sex differences in corticotropin-releasing factor receptor signaling and trafficking: potential role in female vulnerability to stress-related psychopathology. Mol Psychiatry 15:877-904.

Biag J, Huang Y, Gou L, Hintiryan H, Askarinam A, Hahn JD, Toga AW, Dong H-W (2012) Cyto- and chemoarchitecture of the hypothalamic paraventricular nucleus in the C57BL/6J male mouse: a study of immunostaining and multiple fluorescent tract tracing. J Comp Neurol 520:6-33.

Bowen-Pidgeon D, Innamorati G, Sadeghi HM, Birnbaumer M (2001) Arrestin effects on internalization of vasopressin receptors. Mol Pharmacol 59:1395-1401.

Chen C, Jiang Z, Fu X, Yu D, Huang H, Tasker JG (2019) Astrocytes amplify neuronal dendritic volume transmission stimulated by norepinephrine. Cell Rep 29:4349-4361.e4.

Christov-Moore L, Simpson EA, Coudé G, Grigaityte K, Iacoboni M, Ferrari PF (2014) Empathy: gender effects in brain and behavior. Neurosci Biobehav Rev 46:604-627.

Daviu N, Füzesi T, Rosenegger DG, Rasiah NP, Sterley T-L, Peringod G, Bains JS (2020) Paraventricular nucleus CRH neurons encode stress controllability and regulate defensive behavior selection. Nat Neurosci 23:398-410.

de Kloet CS, Vermetten E, Geuze E, Wiegant VM, Westenberg HGM (2008) Elevated plasma arginine vasopressin levels in veterans with posttraumatic stress disorder. J Psychiatr Res 42:192-198.

de Vries GJ (2008) Sex differences in vasopressin and oxytocin innervation of the brain. Prog Brain Res 170:17-27.

Drago F, Stanciu M, Salehi S, Scapagnini U (1997) The block of central vasopressin V1 but not V2 receptors suppresses grooming behavior and hypothermia induced by intracerebroventricular vasopressin in male rats. Peptides 18:1389-1392.

Dumais KM, Veenema AH (2016) Vasopressin and oxytocin receptor systems in the brain: sex differences and sex-specific regulation of social behavior. Front Neuroendocrinol 40:1-23.

Endevelt-Shapira Y, Perl O, Ravia A, Amir D, Eisen A, Bezalel V, Rozenkrantz L, Mishor E, Pinchover L, Soroka T, Honigstein D, Sobel N (2018) Altered responses to social chemosignals in autism spectrum disorder. Nat Neurosci 21:111-119.

Füzesi T, Daviu N, Wamsteeker Cusulin JI, Bonin RP, Bains JS (2016) Hypothalamic CRH neurons orchestrate complex behaviours after stress. Nat Commun 7:11937.

Gillies GE, Linton EA, Lowry PJ (1982) Corticotropin releasing activity of the new CRF is potentiated several times by vasopressin. Nature 299:355357.

Haam J, Halmos KC, Di S, Tasker JG (2014) Nutritional state-dependent ghrelin activation of vasopressin neurons via retrograde trans-neuronalglial stimulation of excitatory GABA circuits. J Neurosci 34:6201-6213.

Hammock EAD, Young LJ (2005) Microsatellite instability generates diversity in brain and sociobehavioral traits. Science 308:1630-1634.

Innamorati G, Sadeghi H, Birnbaumer M (1998) Transient phosphorylation of the V1a vasopressin receptor. J Biol Chem 273:7155-7161.

Innamorati G, Sadeghi H, Birnbaumer M (1999) Phosphorylation and recycling kinetics of G protein-coupled receptors. J Recept Signal Transduct Res 19:315-326.

Insel TR (2010) The challenge of translation in social neuroscience: a review of oxytocin, vasopressin, and affiliative behavior. Neuron 65:768-779.

Iremonger KJ, Bains JS (2009) Retrograde opioid signaling regulates glutamatergic transmission in the hypothalamus. J Neurosci 29:7349-7358.

Jiang Z, Rajamanickam S, Justice NJ (2018) Local corticotropin-releasing factor signaling in the hypothalamic paraventricular nucleus. J Neurosci 38:1874-1890.

Johnson ZV, Young LJ (2017) Oxytocin and vasopressin neural networks: implications for social behavioral diversity and translational neuroscience. Neurosci Biobehav Rev 76:87-98.

Klein B, Bautze V, Maier A-M, Deussing J, Breer H, Strotmann J (2015) Activation of the mouse odorant receptor 37 subsystem coincides with a reduction of novel environment-induced activity within the paraventricular nucleus of the hypothalamus. Eur J Neurosci 41:793-801.

Klein ZA, Romeo RD (2013) Changes in hypothalamic-pituitary-adrenal stress responsiveness before and after puberty in rats. Horm Behav 64:357-363.

Knafo A, Israel S, Darvasi A, Bachner-Melman R, Uzefovsky F, Cohen L, Feldman E, Lerer E, Laiba E, Raz Y, Nemanov L, Gritsenko I, Dina C, Agam G, Dean B, Bornstein G, Ebstein RP (2008) Individual differences 
in allocation of funds in the dictator game associated with length of the arginine vasopressin 1a receptor RS3 promoter region and correlation between RS3 length and hippocampal mRNA. Genes Brain Behav 7:266275.

Knapska E, Mikosz M, Werka T, Maren S (2010) Social modulation of learning in rats. Learn Mem 17:35-42.

Kombian SB, Mouginot D, Pittman QJ (1997) Dendritically released peptides act as retrograde modulators of afferent excitation in the supraoptic nucleus in vitro. Neuron 19:903-912.

Krause J, Ruxton GD (2002) Living in groups. Oxford: Oxford University Press.

Kruk MR, Westphal KGC, Van Erp AMM, van Asperen J, Cave BJ, Slater E, de Koning J, Haller J (1998) The hypothalamus: cross-roads of endocrine and behavioural regulation in grooming and aggression. Neurosci Biobehav Rev 23:163-177.

Kuzmiski JB, Marty V, Baimoukhametova DV, Bains JS (2010) Stressinduced priming of glutamate synapses unmasks associative short-term plasticity. Nat Neurosci 13:1257-1264.

Landgraf R, Neumann ID (2004) Vasopressin and oxytocin release within the brain: a dynamic concept of multiple and variable modes of neuropeptide communication. Front Neuroendocrinol 25:150-176.

Lonstein JS, De Vries GJ (2000) Sex differences in the parental behavior of rodents. Neurosci Biobehav Rev 24:669-686.

Ludwig M (1998) Dendritic release of vasopressin and oxytocin. J Neuroendocrinol 10:881-895.

Ludwig M, Leng G (2006) Dendritic peptide release and peptide-dependent behaviours. Nat Rev Neurosci 7:126-136.

Marshall AD (2013) Posttraumatic stress disorder and partner-specific social cognition: A pilot study of sex differences in the impact of arginine vasopressin. Biol Psychol 93:296-303.

McCormick CM, Mathews IZ (2007) HPA function in adolescence: role of sex hormones in its regulation and the enduring consequences of exposure to stressors. Pharmacol Biochem Behav 86:220-233.

Meisenberg G, Simmons WH (1987) Specific antagonists of the acute behavioral response to centrally-administered vasopressin in mice. Neuropharmacology 26:79-83.

Oliet SHR, Baimoukhametova DV, Piet R, Bains JS (2007) Retrograde regulation of GABA transmission by the tonic release of oxytocin and endocannabinoids governs postsynaptic firing. J Neurosci 27:1325-1333.

Ostrowski NL, Lolait SJ, Young WS (1994) Cellular localization of vasopres$\sin \mathrm{V}$ la receptor messenger ribonucleic acid in adult male rat brain, pineal, and brain vasculature. Endocrinology 135:1511-1528.

Plotsky PM, Bruhn TO, Vale W (1984) Central modulation of immunoreactive corticotropin-releasing factor secretion by arginine vasopressin. Endocrinology 115:1639-1641.
Ramot A, Jiang Z, Tian J-B, Nahum T, Kuperman Y, Justice N, Chen A (2017) Hypothalamic CRFR1 is essential for HPA axis regulation following chronic stress. Nat Neurosci 20:385-388.

Senst L, Baimoukhametova D, Sterley T-L, Bains JS (2016) Sexually dimorphic neuronal responses to social isolation. Elife 5:e18726.

Silk JB (2007) The adaptive value of sociality in mammalian groups. Philos Trans R Soc Lond B Biol Sci 362:539-559.

Son SJ, Filosa JA, Potapenko ES, Biancardi VC, Zheng H, Patel KP, Tobin VA, Ludwig M, Stern JE (2013) Dendritic peptide release mediates interpopulation crosstalk between neurosecretory and preautonomic networks. Neuron 78:1036-1049.

Sterley T-L, Baimoukhametova D, Füzesi T, Zurek AA, Daviu N, Rasiah NP, Rosenegger D, Bains JS (2018) Social transmission and buffering of synaptic changes after stress. Nat Neurosci 21:393-403.

Taylor SE, Klein LC, Lewis BP, Gruenewald TL, Gurung RAR, Updegraff JA (2000) Biobehavioral responses to stress in females: tend-and-befriend, not fight-or-flight. Psychol Rev 107:411-429.

van Erp AMM, Kruk MR, Meelis W, Willekens-Bramer DC (1994) Effect of environmental stressors on time course, variability and form of selfgrooming in the rat: handling, social contact, defeat, novelty, restraint and fur moistening. Behav Brain Res 65:47-55.

van Londen L, Goekoop JG, van Kempen GM, Frankhuijzen-Sierevogel AC, Wiegant VM, van der Velde EA, De Wied D (1997) Plasma levels of arginine vasopressin elevated in patients with major depression. Neuropsychopharmacology 17:284-292.

Wamsteeker Cusulin JI, Füzesi T, Inoue W, Bains JS (2013a) Glucocorticoid feedback uncovers retrograde opioid signaling at hypothalamic synapses. Nat Neurosci 16:596-604.

Wamsteeker Cusulin JI, Füzesi T, Watts AG, Bains JS (2013b) Characterization of corticotropin-releasing hormone neurons in the paraventricular nucleus of the hypothalamus of Crh-IRES-Cre mutant mice. PLoS One 8:e64943.

Wotjak CT, Kubota M, Liebsch G, Montkowski A, Holsboer F, Neumann I, Landgraf R (1996) Release of vasopressin within the rat paraventricular nucleus in response to emotional stress: a novel mechanism of regulating adrenocorticotropic hormone secretion? J Neurosci 16:7725-7732.

Wotjak CT, Ganster J, Kohl G, Holsboer F, Landgraf R, Engelmann M (1998) Dissociated central and peripheral release of vasopressin, but not oxytocin, in response to repeated swim stress: new insights into the secretory capacities of peptidergic neurons. Neuroscience 85:1209-1222.

Young LJ, Wang Z (2004) The neurobiology of pair bonding. Nat Neurosci 7:1048-1054.

Zhang R, Asai M, Mahoney CE, Joachim M, Shen Y, Gunner G, Majzoub JA (2017) Loss of hypothalamic corticotropin-releasing hormone markedly reduces anxiety behaviors in mice. Mol Psychiatry 22:733-744. 